\title{
Market Valuation of Decreases in R\&D Expenditures
}

\begin{abstract}
While many studies report that $R \& D$ investments significantly contribute to firm value, little existing research investigates the effect of the reduction in $R \& D$ expenditures on firm value. This paper examines the long-term performance following significant $R \& D$ decreases. We find that, contrary to conventional wisdom, R\&D decreases enhance rather than destroy shareholder value. We explore three potential economic motives behind $R \& D$ decreases— $R \& D$ spillover, managerial myopia, and overinvestment. We find no compelling evidence to support either the spillover or myopia explanation. However, our results suggest that operating performance deteriorates immediately preceding $R \& D$ decreases and firms with low or decreasing investment opportunities outperform; these findings strongly support the overinvestment hypothesis. We also show that the cost of capital declines after R\&D decreases. However, the market seems to underestimate the improvement in cost of capital following $R \& D$ reductions.
\end{abstract}


Extensive literature reports that firms experience abnormal stock returns following corporate events. For example, Ritter (1991) and Loughran and Ritter (1995) find that firms suffer poor long-run returns after equity offerings. Ikenberry, Lakonishok, and Vermaelen (1995) show that firms generate a positive return drift following open market share repurchase announcements. Other corporate events associated with abnormal long-run performance include stock mergers, debt offerings, and private placements of equity. ${ }^{1}$ In sum, these findings suggest that the market is slow to incorporate the information revealed in some corporate events.

We add to the literature by examining the long-run performance and economic motives associated with significant decreases in research and development (R\&D) expenditures. We focus on R\&D decreases because they differ from previous event studies in two ways. First, recent studies report that the return predictability of growth in the balance sheet, such as asset growth and net share issuance, subsumes the return anomalies associated with equity offerings and share repurchases (Cooper, Gulen, and Schill, 2008; Pontiff and Woodgate, 2008). Because R\&D spending is expensed rather than capitalized, $R \& D$ decreases do not increase or shrink capital and thus firm performance following $R \& D$ decreases is less subject to this growth effect in firms. Second, R\&D investments significantly contribute to the information asymmetry (Aboody and Lev, 2000) and reflect intangible information that investors tend to misprice (Daniel and Titman, 2006). Therefore, R\&D decreases provide an ideal setting to examine whether investors timely adjust their expectations when firms' intangible information changes.

Although all R\&D decisions exhibit these traits, reductions in R\&D offer unique insights into how the market evaluates $R \& D$ investment decisions. First, while $R \& D$ increases merit

\footnotetext{
${ }^{1}$ See, for example, Loughran and Vijh (1997), Spiess and Affleck-Graves (1999), and Hertzel, Lemmon, Linck, and Rees (2002).
} 
some (albeit limited) press coverage, R\&D decreases receive scant, if any, attention. For example, Chan, Martin, and Kensinger (1990) report no cases of pure R\&D reductions in their sample of R\&D announcements between 1979 and 1985. The scarce disclosure in R\&D decreases makes it difficult to predict whether investors are able to see through the impact of R\&D decline. Second, unlike R\&D increases, which are commonly considered good news due to more investment opportunities or better future productivity, R\&D decrease signals are not nearly as clear and thus the valuation of R\&D decreases is not straightforward. On the one hand, managers may reduce $R \& D$ to reflect their expectations on future deteriorating fundamentals, an indication of poor subsequent stock returns. On the other hand, firms may suffer overinvestment problems and thus reduce their R\&D spending to return to the optimal level of R\&D investments. Such an action could mitigate the agency problem and help the firm regain value previously destroyed. As a result, the market valuation following reductions in $\mathrm{R} \& \mathrm{D}$ expenditures is a matter for empirical examination.

Over the last three decades, for Compustat firms with available R\&D information, more than $30 \%$ have decreased their R\&D spending. For these firms, the average reduction in R\&D expenditures is $\$ 2.97$ million, which represents $2.64 \%$ of lagged assets and a $24 \%$ decrease in $R \& D$ growth rate. These statistics suggest that $R \& D$ decreases may have an important impact on firm growth and performance. While a rich literature shows that R\&D investments enhance shareholder value and R\&D increases generate positive abnormal returns in both the short run and the long run, ${ }^{2}$ very few extant papers examine the valuation of R\&D reductions. ${ }^{3}$ In

\footnotetext{
${ }^{2}$ Numerous studies find a positive relation between firms' R\&D and their market value (e.g., Hirschey and Weygandt, 1985; Chauvin and Hirschey, 1993; Hall, 1993b; Fama and French, 1998). Subsequent papers suggest that R\&D levels can predict future stock returns (Lev and Sougiannis, 1996; Chan, Lakonishok, and Sougiannis, 2001). Another branch of literature examines the valuation of R\&D increases. Chan, Martin, and Kensinger (1990) and Szewczyk, Tsetsekos, and Zantout (1996) report a positive market reaction to the announcement of R\&D increases. Eberhart, Maxwell, and Siddique (2004) further extend the literature by showing significantly positive
} 
addition, prior studies find that firms' productivity is highly correlated with R\&D investments and benefits of R\&D can last for 5 to 10 years. ${ }^{4}$ Yet, previous research raises the concern that managers are myopic and may sacrifice long-term profits from $R \& D$ outlays in exchange for increases in short-term earnings (Stein, 1989). The positive relation between the R\&D investments and future benefits, plus the potential managerial myopic behavior, suggests a low market valuation for $R \& D$ decreases. Knowing whether remarkable reductions in $R \& D$ investments indeed create a negative impact on firms' performance is highly valuable to investors.

We decipher the information content of R\&D decreases by asking two questions: (a) How does the market respond to the $R \& D$ decrease, and (b) what factors explain firm performance following $\mathrm{R} \& \mathrm{D}$ decreases? We answer the first question by examining the long-run stock returns after significant $R \& D$ reductions. We use the long-horizon approach because $R \& D$ investments are generally long-term in perspective and an extended period of time may pass before firms realize the total benefits generated from R\&D. To answer the second question, we examine various aspects associated with R\&D decreases, such as operating performance, analysts' forecast revisions, and cost of capital, to understand better why managers significantly reduce their R\&D spending.

We extract 3,594 firm-year observations between 1975 and 2005 from Compustat that have

abnormal stock and operating performance following large R\&D increases. Recently, Hsu (2009) finds that R\&D changes are positively related to future aggregate stock returns in both the United States and major international markets.

3 There are a few papers examining the R\&D decrease in the context of managerial myopia (e.g., Bushee, 1998; Meulbroek, Mitchell, Mulherin, Netter, and Poulsen, 1990). However, none of these papers investigate the valuation of $R \& D$ decreases.

${ }^{4}$ Many economic studies, including Hall (1993a), show that R\&D investments significantly increase the productivity of firms. Lev and Sougiannis (1996) estimate that depending on industries the average duration of R\&D benefit is ranging from 5 to 10 years with an increase of total future earnings between $\$ 1.66$ to $\$ 2.63$ for each $\$ 1$ of current R\&D spending. 
significant and unexpected reductions in R\&D expenditures. We find that, contrary to traditional wisdom, firms experience significantly positive abnormal returns over the five years following large R\&D decreases. The magnitude of abnormal returns is about $0.89 \%$ per month. We control for a variety of return anomaly variables, such as size, book to market, momentum, liquidity, capital expenditure, accruals, net share issuance, and asset growth, and find that these variables do not affect our results.

We perform various robustness checks to verify the positive abnormal returns associated with $R \& D$ decreases. We find that our result is distinct from the R\&D level effect (Lev and Sougiannis, 1996; Chan, Lakonishok, and Sougiannis, 2001) and the R\&D increase effect (Eberhart, Maxwell, and Siddique, 2004). In other words, the abnormal performance following $R \& D$ decreases is not driven by the high $R \& D$ intensity or prior $R \& D$ increases of sample firms. While firms also cut capital expenditures when reducing their R\&D investments, we find that the drift after R\&D reductions is not explained by the negative relation between capital expenditures and stock returns (Titman, Wei, and Xie, 2004). Moreover, prior research suggests that open market share repurchases tend to outperform in the long run (Ikenberry, Lakonishok, and Vermaelen, 1995) and these firms tend to reduce their investments around repurchase announcement (Grullon and Michaely, 2004). Our result does not change by excluding repurchase announcements from our sample. Finally, because we likely pick up the high returns of the uptrend or improvement of a few high-technology industries, we conduct several tests in which we drop some industries or control for the high R\&D level of R\&D-intensive industries; none of these tests change our conclusions. Overall, our results are not explained by high and increasing $R \& D$ intensities, low capital expenditures, significant corporate events, or the high-technology industry effect. These results, along with our control of various anomaly 
variables, mitigate the endogeneity concern that some factors incentivize managers to reduce R\&D spending while these same factors contribute to the return drift following $R \& D$ decreases.

In searching for explanations of return drifts following $R \& D$ decreases, we explore three possible reasons why managers cut R\&D investments—namely, spillover, managerial myopia, and overinvestment-to identify managerial motives for reducing $R \& D$ and to examine their potential impact on stock returns. First, the R\&D spillover effect suggests that one firm's R\&D can benefit other firms' productivity. Managers may cut R\&D investments in anticipation of potential R\&D spillovers. Therefore, the spillover hypothesis predicts that the R\&D spillover will create an improvement in firms' performance following R\&D decreases. However, we do not find improved operating performance following R\&D decreases. As a result, our findings fail to provide evidence consistent with the spillover hypothesis.

Second, the myopic R\&D investment story argues that the R\&D reduction temporarily increases current earnings at the expense of long-term profits. Therefore, the myopic R\&D hypothesis predicts a reversal in firms' performance following R\&D decreases. However, our analysis suggests no apparent reversal in either stock returns or operating performance pursuant to the $R \& D$ decline. Thus, our results indicate that the abnormal returns associated with $R \& D$ decreases are not due to managerial myopia.

Finally, we find that our results are most consistent with the overinvestment explanation. Specifically, we find that firms with low investment opportunities and firms with decreasing growth potentials generate higher long-run returns compared with other R\&D-decrease firms. Firms reduce their cost of capital substantially following decreases in R\&D expenditures. Those firms with a large reduction in cost of capital outperform their R\&D-decrease counterparts who do not experience a significant decrease in cost of capital. In addition, financial analysts 
anticipate poorer earnings, suggesting weakening investment opportunities, only prior to R\&D decreases but not after R\&D decreases. These results support the overinvestment hypothesis, which argues that firms, experiencing a shrinking investment set and thus facing an overinvestment problem, reduce their R\&D intensity to remove inefficient or negative NPV projects. Because $R \& D$ investments are riskier than assets-in-place, reductions in $R \& D$ lower the firm risk and cost of capital (Berk, Green, and Naik, 1999). The observed positive return associated with large R\&D decreases is consistent with the notion that investors underestimate the decline in cost of capital (Grullon and Michaely, 2004).

This paper contributes to the literature in the following two ways. First, this paper is the first study, to the best of our knowledge, that reports positive abnormal returns subsequent to significant declines in R\&D investments. While the extant literature suggests a lower market valuation for R\&D decreases, ${ }^{5}$ our result stands in contrast to this view. We show that a significant reduction in $\mathrm{R} \& \mathrm{D}$ spending, on average, is an indication of overinvestment mitigation and shareholders gain via this value-enhancing action.

Second, previous research shows that R\&D investments represent growth options and are highly correlated with the uncertainty of the stock. However, we find that the market appears to be slow in adjusting to smaller options to grow and to changes in intangible information following R\&D decreases. Therefore, we provide a piece of evidence to support the notion that

\footnotetext{
${ }^{5}$ Because R\&D expenditures are expensed even though they have long-term impact on firms' productivity and performance, the increase (decrease) in R\&D investments will lower (enlarge) current earnings. If investors are misguided by these current earnings to infer future earnings, they may ignore or underreact to the good (bad) information implied from $R \& D$ increases (decreases). As higher (lower) earnings are realized following R\&D increases (decreases), stock returns tend to be high (low). Penman and Zhang (2002) and Lev, Sarath, and Sougiannis (2005) argue that R\&D changes are positively associated with future stock returns and provide some consistent evidence. The previous research also raises the concern of managerial myopia by sacrificing long-term benefits, such as R\&D investments, to maintain a short-term earnings target (Stein, 1989; Graham, Harvey, and Rajgopal, 2005). However, our results do not support the view that large R\&D reductions are associated with lower future returns.
} 
future stock returns are related to intangible information (Daniel and Titman, 2006) and propose a potential explanation to account for this result.

The remainder of the paper is organized as follows. Section I describes our data, the definition of R\&D decreases, and summary statistics. We present our empirical results in Section II. Section III proposes different hypotheses to explain the positive abnormal return associated with decreases in R\&D intensity. The corresponding predictions of each hypothesis are also provided. In Section IV, we examine operating performance, annual abnormal stock returns, analysts' forecast revisions, and changes in cost of capital to test different hypotheses. Section V concludes.

\section{Data}

\section{A. Sample Selection}

Our sample formation begins with firms covered in both the Center for Research in Security Prices (CRSP) and annual Compustat during the period of 1974 to $2006 .{ }^{6}$ We focus on annual R\&D expenditures (Compustat annual data item 46) because quarterly R\&D data are not available until 1989. For each year $t$ from 1975 to 2005, we select firms with a significant reduction in $R \& D$ expenditures. We assume that the $R \& D$ expenditure in the previous year $t-1$ is the expected level of $R \& D$ spending in year $t$. To ensure that $R \& D$ decreases we measure are significant and unexpected, we require sample firms to have (a) the R\&D intensity, measured by R\&D expenditures divided by total assets, of at least $5 \%$ in year $t-1$, and (b) the decrease in

\footnotetext{
${ }^{6}$ The accounting rule in the United States requires that all R\&D spending be expensed in the period incurred and total R\&D be disclosed in the financial statements each year, according to Statement of Financial Accounting Standards No. 2 (SFAS 2). Our R\&D data start from 1974 because the requirement of reporting R\&D (SFAS 2) became effective from 1974 .
} 
R\&D expenditures from year $t-1$ to year $t$ of at least $3 \%$ of total assets in year $t-1 .^{7}$ In other words, our sample firms experienced a reduction in R\&D dollar amounts of at least 3\% of lagged total assets and were R\&D-intensive firms prior to the R\&D decreases. ${ }^{8}$ By using this definition of $R \& D$ decreases, we ensure that sample firms reduce their $R \& D$ investments in dollar amount and that this decrease is economically significant. ${ }^{9}$ We further drop American depositary receipts, closed-end funds, non-U.S. firms, and real estate investment trusts (i.e., require CRSP share code to be 10 and 11) from the sample. The final sample consists of 3,594 firm-year observations from 1,980 firms.

\section{B. Summary Statistics}

Table I presents the summary statistics for sample firms. Panel A reports the sample distribution across cohort years and industries. Our sample clusters in 1990s and 2000s and relates to the surge of high-technological and knowledge-based firms since the 1990s. Because our sample requires the availability of $R \& D$ expenditures, sample firms tend to concentrate in R\&D-intensive industries, such as pharmaceuticals (three-digit SIC 283), computer equipment (three-digit SIC 357), electronic equipment (two-digit SIC 36), measuring equipment (two-digit

\footnotetext{
${ }^{7}$ Throughout the paper, we use year $t$ to represent the ending year of R\&D decreases (i.e., we select sample firms with significant R\&D decreases at the fiscal year-end of year $t$ ), and year $t-1$ as the beginning of $R \& D$ decreases.

${ }^{8}$ Recall that the median ratio of $\mathrm{R} \& \mathrm{D}$ decreases to lagged assets is $2.64 \%$ for all Compustat firms with reductions in R\&D dollar amount. Here, we choose 3\% (i.e., slightly higher than the median) of decreases in R\&D expenditures to lagged assets as the threshold to select our sample because we want to focus on firms with significant R\&D reductions. Our results are qualitatively similar when either $1 \%$ or $5 \%$ is used as the threshold to select the sample. We perform several robustness checks on the sample selection. For example, we (a) drop the requirement of $5 \%$ of the $R \& D$ intensity prior to $R \& D$ decreases, (b) measure the $R \& D$ decrease by requiring the difference between the current R\&D intensity and the average of past five year R\&D intensities from year $t-5$ to year $t-1$ to be at least $3 \%$, and (c) try different scaling variables, such as sales or market value of equity, to define R\&D decreases. Our conclusion does not change with all these abovementioned definitions of R\&D decreases.

${ }^{9}$ Alternatively, we could select sample firms if the decrease in their R\&D intensities (i.e., the R\&D intensity in year $t$ minus the R\&D intensity in year $t-1$ ) is more than 3\%. However, one potential concern of using this definition is that the R\&D decrease may not be due to the reduction in R\&D expenditures but be driven by the increase in firm size. Nevertheless, we try this definition by selecting firms with their R\&D intensity drops more than $3 \%$. The results are qualitatively similar to what we report here. We also retrieve all firms with decreases in R\&D intensities, and sort them into quartiles based on their changes in R\&D intensity. We use the quartile with the most decrease in R\&D intensity as our sample and find similar results.
} 
SIC 38), and software and programming (three-digit SIC 737).

$<$ INSERT TABLE I ABOUT HERE $>$

Panel B of Table I reports firm characteristics. On average, sample firms drop their R\&D spending by $11.4 \%$ (median $=6.8 \%$ ) relative to lagged total assets. As our minimum required decrease in R\&D is only $3 \%$ of lagged total assets, this $R \& D$ decline is remarkably large and represents a $40 \%$ decrease in dollar amount and a 10\% decrease in R\&D intensity. Even after this large reduction in $R \& D$, these $R \& D$-decrease firms still maintain a very high $R \& D$ intensity (mean $=21 \%$; median $=15 \%)$. Similar to R\&D-increasing firms in Eberhart, Maxwell, and Siddique (2004), the R\&D-decrease firms tend to include small growth firms with low median size decile and high Tobin's Q.

Prior research, including Bushee (1998), suggests that firms may cut R\&D outlays to boost current earnings. For such cases where firms manage their earnings by changing $R \& D$ investments, they might also engage in positive accruals manipulation to generate extremely high accruals. However, given the negative accruals shown in our sample (Table I, Panel B), R\&D decreases do not appear to be related to accruals. Moreover, recent literature suggests that long-term tangible investments, such as capital expenditures, are negatively related to future stock returns (Titman, Wei, and Xie, 2004). As Panel B shows, R\&D-decrease firms in our sample do have much lower capital expenditures compared with their previous levels. Later in our empirical analysis, we control for the capital expenditures to ensure that the abnormal performance, if any, following R\&D reductions is not driven by the capital expenditure effect.

In Table II, we present the time series of R\&D intensity, change in $R \& D$, and firm growth around R\&D decreases. To avoid the impact of outliers, we focus our discussion here on median values. Consistent with Table I, our sample firms are R\&D-intensive and growth firms. In 
particular, during the four years prior to $R \& D$ decreases (year -5 to year -2 ), the $R \& D$ intensity is 0.158 and $R \& D$ expenditures grow by $23.7 \%$, amounting to $3 \%$ of lagged total assets. The Tobin's Q, on average, maintains at a level of above 2, implying high growth potentials. In addition, firms enjoy a reasonable growth rate, $11 \%$ in assets and $17 \%$ in sales, during this pre-event period. However, the firm performance turns around in the year preceding the R\&D-decrease year (i.e., year -1 ); assets drop by almost $11 \%$ and sales growth slides from $13 \%$ to just $3.2 \%$. Even though these firms face deteriorating fundamentals, they maintain a fairly high R\&D growth rate of $12.6 \%$. The higher R\&D intensity in year -1 (i.e., $22.6 \%$ vs. $15.8 \%$ in the previous four years) is likely due to lower assets in year -1 because the change in $R \& D$ expenditures relative to lagged assets remains at $2 \%$. In the R\&D-decrease year (i.e., year 0), firms prolong their disappointing growth. After R\&D decreases, the firm growth is substantially lower than the growth before $R \& D$ decreases; the $R \& D$ growth is also lower. Our sample firms clearly experience a significant decline in growth around $R \& D$ decreases, which might be the reason underlying their decision to reduce R\&D spending. Nevertheless, these firms continue to invest heavily in $R \& D$, with $12.2 \%$ of median $R \& D$ intensity over five post-event years, and keep a high Tobin’s Q. Interestingly, very little change in R\&D investment occurs subsequent to the R\&D-decrease year.

\section{$<$ INSERT TABLE II ABOUT HERE $>$}

\section{Empirical Results}

\section{A. Long-Run Stock Returns}

In this section, we examine the long-run abnormal stock return following R\&D decreases. To be consistent with the literature, we first employ the buy-and-hold abnormal return (BHAR) 
approach. BHAR is preferable because the implied investment strategy is both simple and representative of the returns that a long-horizon investor might earn. However, BHAR is skewed to the right and may overstate the long-run performance because it can grow with the return horizon even when there is no abnormal return after the first period (Fama, 1998; Mitchell and Stafford, 2000). Fama suggests examining the average monthly abnormal returns (AARs) to resolve the problems in BHARs because when monthly returns are used, the concern of skewness and overestimation is greatly reduced. To save space, the details of these standard methods are provided the Appendix.

\section{$<$ INSERT TABLE III ABOUT HERE $>$}

In Table III, we report five-year returns subsequent to $R \& D$ decreases. Our results show that firms exhibit large positive returns following R\&D decreases. The raw buy-and-hold return is $118 \%$ over a five-year horizon and is close to the average monthly return of $2 \%$. After controlling for size, book-to-market, and momentum, the abnormal return is still economically and statistically significant—about $0.9 \%$ to $1.0 \%$ in each month during the post-event 60 -months period. This result is not consistent with previous papers which suggest that the R\&D decrease is associated with lower future returns (Penman and Zhang, 2002; and Lev, Sarath, and Sougiannis, 2005).

One potential concern of BHARs and AARs is the strong cross-sectional correlations among sample observations, given that we track long-horizon returns and many sample firms' BHARs and AARs may overlap in several different months. This cross-sectional dependence can lead to poorly specified test statistics (Fama, 1998; Lyon, Barber, and Tsai, 1999; and Brav, 2000). Therefore, we rely on the calendar-time portfolio approach to examine the long-run returns following $R \& D$ decreases. This approach is appealing because the time-series variation of 
monthly portfolio returns accurately captures the effects of correlation across event stocks (Fama, 1998). The abnormal returns can be tested based on the $t$-value of regression intercept alphas.

From July 1977 to December 2006, ${ }^{10}$ a R\&D-decrease portfolio is formed by including firms that were selected as sample observations within past five years. In other words, we treat the large R\&D decreases as a corporate event and examine the impact on stock valuation. As a result, the R\&D-decrease portfolio monthly returns are regressed on Carhart (1997) four factors as follows:

$$
R_{p \tau}-R_{f \tau}=\alpha+\beta\left(R_{m \tau}-R_{f \tau}\right)+s S M B_{\tau}+h H M L_{\tau}+m W M L_{\tau}+e_{\tau},
$$

where $R_{p \tau}$ is the month $\tau$ return of the R\&D-decrease portfolio with $\tau$ within 60 months following June of year $t+1$ where year $t$ is the ending year of R\&D decreases, $R_{f \tau}$ is the risk-free rate, $R_{m \tau}$ is the market portfolio return, $S M B_{\tau}$ is the small-firm portfolio return minus big-firm portfolio return, $H M L_{\tau}$ is the high book-to-market portfolio return minus low book-to-market portfolio return, and $W M L_{\tau}$ is the past winner portfolio return minus past loser portfolio return. ${ }^{11}$ The abnormal returns are measured by regression intercept alphas in equation (1). We perform the $t$-test based on heteroskedasticity- and autocorrelation-corrected standard errors using the Newey and West (1987) method.

Previous studies argue that the abnormal performance (if any) of corporate events occurs in small stocks only (Fama, 1998; Brav, Geczy, and Gompers, 2000). Therefore, as a further check, we implement the calendar-time portfolio approach by applying both equal-weighted and

\footnotetext{
${ }^{10}$ We drop calendar months with less than 25 stocks in the portfolio to avoid the possibility that a few outliers bias our results, although our results hold when imposing different minimum numbers of stocks in a calendar month. Because there are 8 firms selected from the cohort year 1975, 20 firms selected from year 1976, given the requirement of at least 25 firms in the portfolio, our regressions for the full sample effectively start from July 1977.

${ }_{11}$ We appreciate that Professor Kenneth French kindly makes the factor data available on his website, http://mba.tuck.dartmouth.edu/pages/faculty/ken.french/.
} 
log-value-weighted formation strategies. We use log-value weights, however, rather than unadjusted value weights to reduce the perverse impact of including extremely large firms. With such big firms in the sample, estimating calendar time performance using a value-weighting scheme leads to a least powerful test to detect abnormal stock returns (Loughran and Ritter, 2000). The lack of power is an important and valid concern in this paper as our R\&D-decrease firms tilt toward small firms. Fama and French (2008) also argue that value-weighted portfolio returns can be dominated by a few large stocks and may not be able to capture the potential return anomaly associated with firms.

Table IV shows the five-year abnormal stock returns based on the calendar-time portfolio regression approach. R\&D-decrease firms exhibits high betas and their stock returns load positively on the size factor and negatively on the book-to-market factor-a result that is consistent with Table I where firms with R\&D decreases tend to be small growth firms. The monthly abnormal return is $1.14 \%$ in the equal-weighted case and $0.89 \%$ in the log-value-weighted case. Both returns are significant within a $1 \%$ level and are comparable to those in Table III.

\section{$<$ INSERT TABLE IV ABOUT HERE $>$}

Next, we focus on the relation between the firm size and abnormal returns of R\&D-decrease firms. As shown in Table I, R\&D-decrease firms tend to be small firms. The positive returns we observe in Table III and Panel A of Table IV could be driven by very tiny firms even though we have controlled for the size factor in the regression model. To test this idea, we partition the sample firms into small (i.e., smaller than the sample median of market capitalization) and large firms in each cohort year and report their abnormal returns in Table IV, Panels B and C, respectively. The equal-weighted abnormal return of small firms is $1.73 \%$, which is more than 
double of the $0.68 \%$ abnormal return of large firms. Although the abnormal return is much higher in small firms, the subsample of larger firms also generates significant positive returns. This result suggests that the positive return drift following R\&D decreases is not entirely driven by the small firms in our sample. ${ }^{12}$

Moreover, we perform three additional tests to examine the impact of firm size on our results. To save space, we do not tabulate these results. First, because the size effect is largely driven by January months, we skip all months of January when we run the regression equation (1). The abnormal returns for equal-weighted and log-value-weighted cases are $0.46 \%$ and $0.30 \%$, respectively. Although these abnormal returns are greatly reduced after excluding Januaries, they are still significant within a 10\% level. Second, we control for the low-price effect (Loughran and Ritter, 1996) because small firms tend to be low priced. We drop firms with share price below $\$ 5$ from the R\&D-decrease portfolio and find the equal-weighted and log-value-weighted returns are $0.72 \%(p$-value $=0.031)$ and $0.57 \%(p$-value $=0.063)$, respectively. Finally, we drop sample firms with total assets smaller than $\$ 10$ and $\$ 20$ million, respectively, and find that abnormal returns associated with R\&D decreases are similar to what we report here. All these findings indicate that the abnormal performance of R\&D-decrease firms is not accentuated in small firms only.

\section{B. Robustness Checks}

In this section, we perform various robustness checks on stock returns of R\&D-decrease firms. In particular, we examine whether the positive return drift following large reductions in $\mathrm{R} \& \mathrm{D}$ investments is driven by potential biases in computing abnormal stock returns (e.g.,

\footnotetext{
${ }^{12}$ We also use the NYSE bottom size decile cutoffs (rather than the sample median firm size) to classify sample firms as small and big firms. The equal- (log-value-) weighted abnormal return is $0.69 \%(0.61 \%)$ with a $p$-value of $0.053(0.071)$ for big firms, and $1.41 \%(1.18 \%)$ with a $p$-value of $0.003(0.009)$ for small firms.
} 
time-varying factor loadings, survivorship bias, and overlapping data), return anomalies reported in the literature, or some subsets of the sample. Because the R\&D investment decision is generally endogenous, these robustness checks would help to mitigate the concerns that our results are driven by some unknown factors. To save space, we report only alphas of regression equation (1) and their statistical significance.

Because a firm's risk may change in response to its R\&D changes (Chan, Lakonishok, and Sougiannis, 2001; Berk, Green, and Naik, 2004), we follow Eberhart, Maxwell, and Siddique (2004) and use a rolling-over method to control for any potential time-varying risk in equation (1). In particular, we use the first 60 monthly returns (i.e., from July 1977 to June 1982) of the portfolio to estimate its factor loadings and calculate the expected portfolio return in month 61 (i.e., July 1982) based on these factor loadings estimated over the previous 60 months multiplied by their corresponding factor returns in month 61 . The abnormal return in month 61 is the difference between the actual portfolio return and expected portfolio return. This step is repeated every month with rolling-over factor loadings. We average these monthly abnormal returns across time and perform the significance test based on time-series standard errors.

To account for any possible survivorship bias in our sample firms, we perform a delisting control by assigning the delisted return from CRSP as the last return of firms that are delisted during our return calculation period. For firms delisted for performance reasons, we follow the suggestions by Shumway (1997) and Shumway and Warther (1999) to use -0.30 as the last return for NYSE/AMEX stocks and -0.55 for Nasdaq stocks.

Another potential concern for our results is the overlapping data problem that high growth firms are repeatedly selected into the sample. To address this issue, we construct a five-year sample in which a firm can only be included in the sample once every five-year period. 
The results of controlling for these potential biases are presented in Panel A of Table V. We find that no matter which bias we control, both equal-weighted and log-value-weighted abnormal returns are positive within the $5 \%$ significance level. These results suggest that the return drift reported in Table IV for R\&D-decrease firms is robust and not driven by time-varying factor loadings, survivorship bias, or overlapping data.

\section{$<$ INSERT TABLE V ABOUT HERE >}

Is it possible that the positive abnormal return following large R\&D reductions is related to anomaly variables that significantly explain the cross-section stock returns? For example, recent papers find that stock returns are negatively related to a variety of variables, including accruals (Sloan, 1996; Chan, Chan, Jegadeesh, and Lakonishok, 2006), asset growth (Cooper, Gulen, and Schill, 2008), net share issuance (Fama and French, 2008; Pontiff and Woodgate, 2008), net operating asset (Hirshleifer, Hou, Teoh, and Zhang, 2004), and liquidity (Pastor and Stambaugh, 2003). The literature also suggests that small market cap is generally correlated with low growth in assets, negative accruals, low net operating assets, and low liquidity—all of which predict positive future returns. Because R\&D-decrease firms tends to be small companies, our findings could potentially be affected by these anomalous patterns in stock returns. Moreover, the summary statistics in Table I suggest that R\&D- decrease firms exhibit high $R \& D$ levels and low abnormal capital expenditures, and stocks with such firm characteristics tend to generate better future performance (Lev and Sougiannis, 1996; Titman, Wei, and Xie, 2004).

To account for these return anomalies reported in the literature, we construct one factor-mimicking portfolio for each anomaly variable and add its return into equation (1) as an additional factor to form the five-factor model. The detailed definition of anomaly variables and their corresponding portfolio formation are reported in the Appendix. Panel B of Table V 
presents the abnormal returns of these five-factor models. When we control for factors of asset growth, capital expenditure, net share issue, and net operating assets individually in the five-factor model, the abnormal return of R\&D-decrease firms is similar to that in Table IV with about $0.87 \%$ to $0.93 \%$ per month in the log-value-weighted case. This result suggests that R\&D decreases are not highly correlated with firm growth factors. Adding the accruals, liquidity or R\&D factor into the four-factor model reduces the return drift to about $0.81 \%$ per month (log-value-weighted case). All of these abnormal returns are significant within a 2\% level. Finally, although not tabulated here, we add into the Carhart (1997) four-factor model all factors listed in Panel B to control for these return anomalies simultaneously. The equal- (log-value-) weighted abnormal return is $0.97 \%(0.72 \%)$, with a $p$-value of $0.001(0.006)$. Overall, our results in Panel B show that the return anomalies reported in the recent literature do not subsume the abnormal return associated with R\&D-decrease firms.

Are our results related to the long-run return reversal in stock returns (DeBondt and Thaler, 1985, 1987)? One might argue that R\&D-decrease firms perform poorly prior to the portfolio formation and the subsequent return reversal contributes to the positive return drift following $\mathrm{R} \& \mathrm{D}$ decreases. To test this possibility, we first examine three- and five-year returns prior to the portfolio formation based on the factor model regression (1). Neither the equal-weighted return nor log-value-weighted return is significant. Then, we sort the sample firms into the winner and loser portfolios based on their past raw buy-and-hold returns and test whether only the loser portfolio earns future profits. We find that both winner and loser portfolios generate significantly positive abnormal returns. These results suggest that past returns are not likely to be the factor to drive our results.

To perform further checks on our results, in Panel C of Table V, we separately exclude some 
subsets of R\&D-decrease firms with extreme firm characteristics or major corporate events that exhibit abnormal future performance. First, to check whether our results are related to the high R\&D intensity and low capital expenditure, we drop R\&D-decrease firms in the highest quartile of R\&D-to-asset ratio and the lowest quartile of abnormal capital expenditure, respectively. The result shows that the abnormal return of $R \& D$-decrease firms remains significant after eliminating high R\&D or low capital expenditure firms, suggesting that the abnormal return of R\&D-decrease firms is not driven by the R\&D effect (Lev and Sougiannis, 1996; Chan, Lakonishok and Sougiannis, 2001) or capital investment effect (Titman, Wei and Xie, 2004) in stock returns. Second, it is likely that some R\&D-decrease firms experience a large swing in $R \& D$ and significantly increase their R\&D spending prior to large R\&D decreases. Eberhart, Maxwell, and Siddique (2004) find a positive abnormal return following large R\&D increases, which may account for our findings. To address this concern, stocks that experienced a large R\&D increase as defined in Eberhart, Maxwell, and Siddique in any of the past five years are removed from the R\&D-decrease portfolio. The result shows an equal-weighted return of 1.07\% and a log-value-weighted return of $0.80 \%$ after controlling for significant increases in $R \& D$ investments. These numbers are comparable to those in Table IV, suggesting that the $R \& D$ decrease effect we report here is not the manifestation of $R \& D$ increase effect.

Moreover, the previous literature shows a positive return drift following share repurchase programs (Ikenberry, Lakonishok, and Vermaelen, 1995). Grullon and Michaely (2004) find that firms reduce investments (including capital expenditure and R\&D) around their buyback announcements. These results raise the possibility that the favorable stock performance of R\&D-decrease firms could be driven by return drifts associated with share repurchases. To control for the repurchase effect, we discard R\&D-decrease firms that announced open market 
share repurchases in the five years prior to portfolio formation. The abnormal returns of the R\&D-decrease portfolio remain strong when repurchase firms are eliminated. This result suggests that the return drift following large $R \& D$ reductions is distinct from the positive abnormal performance of repurchase firms.

Another concern is whether our result is driven by the large premium associated with the merger transactions in which R\&D-decrease firms are acquired subsequent to their decreases in R\&D. We address this concern by removing R\&D-decrease firms that involve M\&A transactions as the target, based on SDC M\&A database, in any of five years after large R\&D reductions. The abnormal return after taking out target firms is very close to the return based on the full sample in Table IV. The result suggests that the superior stock performance of R\&D-decrease firms is not related to M\&A transactions.

In Panel D of Table V, we examine the potential impact of industry effects. Because R\&D-decrease firms tend to keep intensive $R \& D$ investments, one may argue that the positive abnormal return of the R\&D-decrease portfolio is driven by the large stock returns associated with one or two high-technology industries. To address this issue, we re-define R\&D-decrease firms as firms with (a) a R\&D intensity of more than $5 \%$ and (b) a reduction in industry-adjusted $R \& D$ of more than $3 \%$, where the industry-adjusted $R \& D$ change is the sample firm's change in $\mathrm{R} \& \mathrm{D}$, defined as the dollar amount change in $\mathrm{R} \& \mathrm{D}$ expenditures divided by lagged total assets, minus the corresponding industry median change in R\&D. For this industry-control approach, both equal-weighted and log-value-weighted results are significant, with the log-value-weighted return equal to $0.90 \%$. Moreover, because our sample concentrates on only a few industry groups (i.e., pharmaceuticals, computer and electronic equipment, and software and programming), we investigate the impact of each single industry by excluding one industry at a time from our 
sample. In particular, we drop the industry with one-digit SIC 2, 3, and 7, separately, from the full sample. The abnormal returns are significant no matter which industry we eliminate from the sample. All these findings suggest that our main results are not likely to be driven by only one or two industry groups.

Finally, we examine the future returns following $R \& D$ decreases via a zero-investment portfolio approach. In particular, we form a zero-investment portfolio by buying R\&D-decrease firms and selling their corresponding matching firms and regress the zero-investment portfolio returns against Carhart's (1997) four factors. In other words, we replace the dependent variable in equation (1) by the return difference between sample firms and their matching firms. We employ three methods to obtain matching firms. The first matching firm is chosen from the same two-digit SIC industry with the closest pre-event (i.e., at the beginning of the R\&D-decrease year) return on assets (ROA) as of the sample firm. The second matching firm is selected with the same two-digit SIC industry and the closest sum of pre-event ROA and post-event (i.e., at the ending of the R\&D-decrease year) $R \& D$ intensity as of the sample firm. The last control firm is matched by size, book-to-market, and momentum. All matching firms are required to be nonsample firms; that is, the matching firms do not have significant R\&D decreases in any of the past five years.

Table V, Panel E presents the zero-investment portfolio results. When controlling for the industry and past performance, both equal-weighted and log-value-weighted abnormal returns are economically and statistically significant. Even with the R\&D intensity as a further control, the $R \& D$-decrease firms still generate an abnormal return of $0.41 \%(0.18 \%)$ in the equal(log-value-) weighted case. Both results suggest that the return drift following R\&D decreases is not entirely driven by the concentration of our sample in high-technology industries and with 
high R\&D intensity. Finally, we show that when important return attributes are controlled for (i.e., size, book-to-market, and momentum), the abnormal returns associated with the R\&D decrease remain strong, with the log-value-weighted return of about $0.70 \%$ per month.

In sum, the positive abnormal return following $R \& D$ reductions is robust with respect to potential bias controls and inclusion of return anomalies. Moreover, our result is not driven by specific subsets of the full sample. The industry effect cannot explain our results either. Our result suggests that decreasing R\&D enhances, rather than destroys, shareholder value.

\section{Hypotheses and Predictions}

In this section, we propose three hypotheses to account for the abnormal returns following reductions in $R \& D$ investments. These hypotheses are related to economic reasons why firms significantly reduce their R\&D investments. By examining the managerial motives behind $R \& D$ decreases, we are able not only to better understand the return pattern associated with $R \& D$ reductions, but also to gain insight into firms' investment decisions. We also provide some predictions for each hypothesis.

\section{A. Spillover Hypothesis}

Several papers (e.g., Griliches, 1979) point out the existence of R\&D spillover effect in which one firm’s R\&D activity benefits other firms’ productivity. With R\&D spillovers, a firm’s R\&D investment not only reduces its own production cost but also lowers the costs of other firms' research efforts. The literature suggests that $R \& D$ spillovers increase profits and reduce variable costs of firms (Jaffe, 1986; Bernstein and Nadiri, 1988). Megna and Klock (1993) show that in the semiconductor industry firm value increases due to higher R\&D investments by rival firms. In addition, Hunt (2006) suggests that a firm might reduce its R\&D spending if patents are 
less expensive than the cost of R\&D investment.

In anticipation of future potential $R \& D$ spillovers, managers may reduce their firms’ $R \& D$ expenditures and still maintain their firms' competitiveness in the product market. Ceteris paribus, the lower R\&D spending decreases firms’ expenses and increases firms’ current and future earnings. The positive abnormal stock returns following large $R \& D$ decreases could be driven by the better profitability due to R\&D spillovers from other firms. Therefore, the spillover hypothesis predicts improved operating performance following R\&D decreases. Moreover, within an industry, the benefit of R\&D spillover could accrue less to high R\&D firms because these firms have likely already obtained the knowledge or network of spillovers by their own intensive R\&D investments. Thus, the spillover story also predicts that firms with lower R\&D in an industry will enjoy a higher R\&D spillover effect and thus generate better stock and operating performance following $R \& D$ decreases.

\section{B. Managerial Myopia Hypothesis}

Stein (1989) argues that managers who are concerned about the high stock price or stock market pressure will undertake myopic behavior by cutting investment projects, such as $R \& D$ outlays, to boost short-term earnings. Although current earnings increase to a level higher than they would otherwise be, future earnings are dampened due to lower current investments, thus creating a negative long-term impact on firms. Bushee (1998) finds evidence that managers trim down $R \& D$ to reverse an earnings decline when institutional ownership (IO) is low.

One implication of managerial myopia on $R \& D$ is that firms will experience a performance reversal. In particular, the reduction in $R \& D$ reduces expenses and creates higher earnings. If the market does not see through this earnings manipulation and extrapolates earnings growth, the 
stock returns may increase. However, the R\&D reduction may lower future growth opportunity and reduce the competitive advantage of firms in the product market. As a result, the future earnings tend to be low and abnormal stock returns tend to be negative. Under this managerial myopia hypothesis, the positive abnormal returns associated with R\&D decreases is probably attributed to the initial large stock returns, in response to unexpected higher earnings due to reduced R\&D expenditures, which average out the poor subsequent performance. Moreover, because firms with low IO are more likely to invest myopically by cutting down R\&D (Bushee, 1998; Roychowdhury, 2006), the myopia hypothesis predicts a more significant performance reversal for R\&D-decrease firms with low IO. If the return drift following $R \& D$ decreases is driven by the market inability to recognize the earnings manipulation via changes in $R \& D$ investments, we expect to observe more abnormal returns for low IO firms.

\section{Overinvestment Hypothesis}

Firms may reduce R\&D expenditures to mitigate or eliminate the overinvestment problem. Jensen (1986) argues that managers tend to perform empire-building behavior, a conduct which causes firms to grow beyond the optimal size and destroys firm value. This overinvestment or agency problem is most severe for firms with low investment opportunities and firms with large decreases in growth potentials. To mitigate such an agency problem, firms may reduce their R\&D spending to recap firm value that is destroyed by undertaking negative NPV projects. Under this scenario, large $R \& D$ decreases can accompany better future stock performance due to the removal of inefficient projects.

There are five predictions associated with this overinvestment story. First, the overinvestment problem suggests that firms have fewer profitable projects to invest and face a 
shrinking investment opportunity set and deteriorating profitability. As a result, the overinvestment hypothesis predicts a weakening operating performance around R\&D decreases. Second, if firms cut down R\&D in response to the fewer available projects, we argue that the declining investment opportunity is also anticipated by financial analysts. As a result, we expect to observe a downward revision of analysts' forecasts prior to firms reducing their $R \& D$ investment. Third, with lower growth potentials, firms lower their R\&D outlays and thus reduce their firm risks as assets in place take a large portion in determining firm value (Berk, Green, and Naik, 1999; Carlson, Fisher and Giammarino, 2004). The reduced firm risks are expected to be accompanied by a lower cost of capital. Accordingly, the cost of capital after the R\&D decrease is predicted to decline. Fourth, Grullon and Michaely (2004) find that investors underestimate the decline in cost of capital following open market share repurchases. It is likely that the positive return drift for firms with $R \& D$ reductions is driven by the incorrect market inference in the decline of cost of capital; the more the decrease in cost of capital, the larger the abnormal stock returns. Finally, because low growth firms and firms whose investment opportunities decline have few options to grow-a situation that is more likely to incur overinvestment problems (Jensen, 1986) — they are expected to enjoy higher returns when $R \& D$ activities are reduced to mitigate the overinvestment problem.

\section{Hypotheses Testing}

In this section, we investigate different aspects of firms that have significantly reduced their R\&D intensity. We test our three hypotheses by examining operating performance, annual abnormal stock returns, analysts' forecast revisions, and changes in cost of capital. We also examine the hypothesis predictions via multiple regression analysis. 


\section{A. Operating Performance}

The first test we conduct to verify our three proposed hypotheses is the operating performance. If the spillover hypothesis is correct, we expect to observe improving profitability following R\&D reductions. On the other hand, the overinvestment story predicts deteriorating operating performance around R\&D decreases. Finally, if the managerial myopia accounts for our results, the operating performance should reverse in the long-run.

We measure operating performance based on ROAs, defined as earnings before interest, tax and depreciation (EBITDA; Compustat item 13) plus after-tax R\&D expenditure (Compustat item 46) scaled by average total assets. We use EBITDA to gauge profitability because it is not affected by changes in capital structure or by special items and income taxes that influence other measures of earnings (Barber and Lyon, 1996). We further adjust EBITDA with after-tax R\&D expenses because our sample firms are $R \& D$ intensive and their earnings might be underestimated due to immediate expensing of high R\&D expenditures.

The literature suggests that the abnormal operating performance provides a more reliable measure of firms’ profitability. For example, Fama and French (2000) argue that the life cycle theory of firms predicts a decline in unadjusted operating performance in a long panel study. As a result, the earnings are prone to be mean reverting in a relative short window. By controlling for this mean-reverting feature of earnings, the measure of abnormal operating performance would generate a better and cleaner test on profitability. Therefore, we also examine abnormal operating performance.

Here, the abnormal operating performance is defined as the ROA of a R\&D-decrease firm minus ROA of a control firm matched with the industry, pre-event earnings, and R\&D level. 
Barber and Lyon (1996) find that the abnormal operating performance based on the industry and performance-matched control firm can generate well-specified tests. We further control for the $R \& D$ level to mitigate the potential effect of high $R \& D$ firms that may generate better operating performance (Eberhart, Maxwell, and Siddique, 2004). The details of computing abnormal operating performance are provided in the Appendix.

The empirical results of operating performance are presented in Table VI. ${ }^{13}$ We focus on median operating performance as it exhibits superior statistical power by reducing the impact of outliers (Barber and Lyon, 1996). Panel A reports the level of operating performance. For the raw ROA, a reversal is found at the time when firms reduce their R\&D. Prior to R\&D decreases, the ROA deteriorates from $2.79 \%$ (year -5 ) to $-6.7 \%$ (year -1 ); after the R\&D decrease, firms' earnings improve from $-4.1 \%$ (year 0 ) to $2.5 \%$ (year 5 ). Clearly, we need to control for this mean-reverting pattern by examining the performance-matched abnormal earnings. When we control for the matching firm performance, the abnormal ROAs do not exhibit any significant pattern after R\&D decreases, but earnings are significantly poor (-0.03\%) right before $R \& D$ decreases.

\section{$<$ INSERT TABLE VI ABOUT HERE $>$}

As in Panel A of Table VI, the changes in ROA reported in Panel B show a consistent pattern. The unadjusted ROAs deteriorate prior to R\&D decreases but improve during year 1 . When we control for the mean-reverting pattern, firms perform poorly during year -1 , the year immediately preceding $R \& D$ decreases. The poor earnings generated in year -1 match the timing of turnaround in firm growth in Table II and explain why firms have a substantial decline in

\footnotetext{
${ }^{13}$ To reduce the impact of extreme outliers due to small assets in the denominator of ROAs, we drop firms with assets and sales less than $\$ 3$ million. However, our results are fairly robust without this firm size requirement or with different exclusion criteria.
} 
assets growth right before $R \& D$ decreases. After $R \& D$ decreases, no significant abnormal change is found in ROAs except in year 4. Over the five-year period after the decline in $R \& D$ expenditures (i.e., during year 1 to year 5), the abnormal change in ROA (not tabulated here) is 0.74\%, which is insignificant $(p$-value $=0.15)$.

In untabulated results, we examine the operating performance using a modified partial adjustment model. This model is suggested by Fama and French (2000) to control for mean reverting and nonlinearities in the relation between future changes in operating performance and lagged levels and changes in operating performance. Grullon and Michaely (2004) employ this approach to examine the operating performance following repurchase announcements (see their Table III for model specifications). We find that after controlling for the nonlinearities in earnings, R\&D-decrease firms exhibit a significant negative change in earnings during the year prior to $\mathrm{R} \& \mathrm{D}$ decreases (i.e., in year -1 ), and no remarkable improvement or deterioration in ROAs occurs after R\&D decreases. These results are consistent with what we report in Table VI.

We also examine whether the operating performance differs between low and high IO firms and between $R \& D$ followers, whose $R \& D$ is below their industry median, and $R \& D$ leaders. If the spillover hypothesis is correct, we expect to observe a better performance for R\&D followers because they are more likely to obtain the benefit of R\&D spillovers. If the myopia story is true, low IO firms should exhibit more abnormal performance as managers in these firms are more likely to manipulate earnings by changing their R\&D investment policy. Although there is some evidence that $R \& D$ followers generate slightly better earnings in the first year following $R \& D$ decreases, the results show no significant difference in changes in ROAs between $R \& D$ followers and leaders over five post-event years. The change in ROAs is not significantly different either between low and high IO firms. To save space, these results are not reported 
here.

Overall, we do not find that the abnormal operating performance of R\&D-decrease firms improves over time. This result is not consistent with the R\&D spillover hypothesis, which predicts an enhancement in operating performance for R\&D-decrease firms. Moreover, we do not find an evident reversal in operating performance, which is expected by the myopia hypothesis. The results conditioning on $R \& D$ followers versus $R \& D$ leaders and low IO versus high IO firms paint the same conclusion. However, our results, along with the decreasing pattern in growth reported in Table II, are consistent with the overinvestment story that R\&D-decrease firms face a declining investment opportunity set and promptly react to reduce $R \& D$ expenditures to mitigate potential agency costs of overinvestment.

\section{B. Annual Abnormal Stock Returns}

To test the managerial myopia hypothesis, we examine annual abnormal stock returns over five years following significant R\&D decreases to investigate whether a return reversal is found. The results are reported in Table VII. For the full sample, we do not find a return reversal pattern. Both equal-weighted and log-value-weighted returns are positively significant from year 1 to year 5. In any case, we do not observe significantly negative returns across the five-year horizon. ${ }^{14}$ Moreover, we divide the R\&D-decrease firms into high and low IO groups, where IO is the total shares owned by institutions, obtained from Thomson Reuters $13 \mathrm{f}$ database at the beginning of the R\&D-decrease year, divided by total shares outstanding. We find that the high IO group performs better than low IO firms over the five-year period following R\&D decreases

\footnotetext{
${ }^{14}$ In an unreported test, we extend the stock return examination to a 10-year horizon and do not find a significant return reversal in either the full sample or the IO sub-samples. We also examine the five-year abnormal returns for $R \& D$ leaders and $R \& D$ followers, respectively. While $R \& D$ followers generate higher abnormal returns than $R \& D$ leaders, the difference is not statistically significant.
} 
(1.12\% vs. $0.89 \%$ in the log-value-weighted case), although the difference between two groups is not statistically significant (not reported here). Again, we do not observe any evidence that low IO firms exhibit a strong and consistent return reversal. Although the literature argues that managers, especially those in firms with low IO, may behave myopically to cut R\&D investments to create a turnaround in performance, our results in Table VII do not support this view.

$<$ INSERT TABLE VII ABOUT HERE $>$

\section{Analysts’ Forecast Revisions}

The deteriorating operating performance prior to R\&D decreases observed in Table VI supports the overinvestment hypothesis. To address the question of whether managers cut $R \& D$ to respond to weakening investment opportunities, we examine whether the market anticipates a shrinking investment set for R\&D-decrease firms. In particular, we use analysts’ forecasts as the proxy for the market perception of firms' future performance. To test the overinvestment hypothesis, we check whether analysts revise their forecasts downward prior to the managerial decision to reduce $R \& D$ expenditures. The results here can also serve as an alternative approach to disentangle the three hypotheses. If the spillover hypothesis is correct, upward forecast revisions around $R \& D$ decreases would be expected due to improved profitability. On the other hand, if the managerial myopia story is true, because firm performance tends to reverse subsequently, a reversal in analysts' forecast revisions after R\&D decreases may be observed.

We follow Brous and Kini (1993) to measure the abnormal forecast revisions with a fourth-order moving-average adjustment. The forecast revision is measured by the mean earnings forecast minus the mean forecast in the previous month and scaled by the stock price. The abnormal forecast revision in month $\tau$ is equal to the month $\tau$ forecast revision, subtracting two 
terms: (a) the forecasted component, defined as the average of forecast revisions of all months in IBES excluding months $(\tau-12, \tau+12)$ and (b) the four-month moving-average of unexpected components, where the unexpected components are the difference between the forecast revisions and forecasted components in the past four months. Abnormal forecast revisions are winsorized at the top and bottom $1 \%$.

Table VIII presents regression results of abnormal forecast revisions. The dependent variables are the abnormal forecast revisions in the 72 months around each fiscal year $t$. To increase the test power, we include all firms covered in IBES and stack all fiscal years in the regressions. All independent variables, except the R\&D decrease dummy ( $L D R D)$, are measured at the fiscal year-end. $L D R D$ is a dummy variable that equals 1 if the firm has the R\&D-to-asset ratio of more than $5 \%$ in year $t-1$ and the decrease in $R \& D$ dollar amounts from year $t-1$ to year $t$ of more than $3 \%$ of lagged total assets, and zero otherwise. In other words, $L D R D$ represents firms experiencing large decreases in $\mathrm{R} \& \mathrm{D}$ expenditures between year $t-1$ and year $t$. $L D R D^{*} F R(-1)$ is a dummy variable that equals 1 if the firm experienced significant $R \& D$ reductions between year $t-1$ and year $t$ and the forecasts revisions were made during year -1 , the year prior to the large $R \& D$ decreases, and zero otherwise. $L D R D^{*} F R(-2), L D R D^{*} F R(-3)$, and so on are defined in a similar fashion. Other control variables include size, book-to-market, momentum (the prior return), and R\&D expense.

$<$ INSERT TABLE VIII ABOUT HERE $>$

In Model 1, the coefficient of $L D R D$ is -2.07 ( $t$-statistics $=-3.17$ ), suggesting that analysts revise earnings forecasts downward around reductions in R\&D investments. In Model 2, we test the forecast revisions for each of three years before and three years after R\&D decreases, separately. The analysts' forecast revision for R\&D-decrease firms is significantly positive 
during year -3 . The revision continues to be positive in year -2 , although insignificant. However, the analysts change their opinions and turn to be pessimistic for R\&D-decrease firms during year -1 , with a coefficient of -2.83 and $t$-statistics equal to $-1.97 .{ }^{15}$ We find no significant download revisions after R\&D decreases. The fact that downward revisions occur immediately before the R\&D decrease decision is consistent with the result in Table VI, where the abnormal operating performance deteriorates prior to $\mathrm{R} \& \mathrm{D}$ decreases. These results are consistent with the overinvestment hypothesis but not the spillover or myopia hypothesis. The results suggest that the market anticipates the future declining investment opportunity and profitability of R\&D-decrease firms. Managers of these firms may possess the same perception and cut R\&D accordingly to reduce potential overinvestment problems.

\section{Changes in Cost of Capital}

Next, we examine changes in cost of capital around the R\&D-decrease portfolio formation. Under the overinvestment hypothesis, growth opportunities shrink over time and firms may undertake negative NPV projects, thus creating the agency problem. In an attempt to mitigate this overinvestment problem, firms may drop some risky projects, such as R\&D expenditures. The lower R\&D investments reduce not only the growth option but also the uncertainty of firms' future prospect (Berk, Green, and Naik, 1999; Carlson, Fisher, and Giammarino, 2004). As a result, the systematic risk associated with R\&D decreases would decline.

We follow an approach similar to Grullon and Michaely (2004) and measure the cost of capital for each sample observation by the following Carhart's (1997) four-factor model using

\footnotetext{
${ }^{15}$ In unreported results, we include the R\&D increase dummy in both Models 1 and 2 to control for the potential mean-reverting pattern associated with R\&D increases. The results are very similar to what we report in Table VIII. This finding suggests that the negative coefficients of $L D R D$ and $L D R D^{*} F R(-1)$ are not driven by the outperformance of R\&D-increase firms.
} 
120 monthly returns around July of year $t$, where the R\&D decrease is measured at the fiscal years of $t-1$ and $t:^{16}$

$$
\begin{aligned}
R_{i \tau}= & R_{f \tau}+a_{-i}+a_{\Delta i} D_{\tau}+b_{-i}\left(R_{m \tau}-R_{f \tau}\right)+b_{\Delta i} D_{\tau}\left(R_{m \tau}-R_{f \tau}\right)+ \\
& S_{-i} S M B_{\tau}+s_{\Delta i} D_{\tau} S M B_{\tau}+h_{-i} H M L_{\tau}+h_{\Delta i} D_{\tau} H M L_{\tau}+m_{-i} W M L_{\tau}+m_{\Delta i} D_{\tau} W M L_{\tau}+\varepsilon_{p \tau},
\end{aligned}
$$

where $R_{i \tau}, R_{f \tau}, R_{m \tau}, S M B_{\tau}, H M L_{\tau}$, and $W M L_{\tau}$ are defined similarly as in equation (1); $D_{\tau}$ is a dummy variable that equals 1 if month $\tau$ is on or after July of year $t$; $a_{-i}$ is the abnormal return and $b_{-i}, s_{-i}, h_{-i}$ and $m_{-i}$ are the factor loadings of firm $i$ during the period from July of year $t-5$ to June of year $t ; a_{\Delta i}$ is the change in abnormal return, and $b_{\Delta i}, s_{\Delta i}, h_{\Delta i}$ and $m_{\Delta i}$ are the changes in factor loadings during the period from July of year $t$ to June of $t+5$. The cost of capital is evaluated at the average $R_{f}, R_{m}-R_{f}$, and risk premiums of $S M B, H M L$, and $W M L$ over the period of 1976 to 2006. The abnormal cost of capital is the unadjusted cost of capital minus the cost of capital of a control firm matched with the market value of equity, book-to-market, prior one-year return (excluding month -1 ), and $R \& D$ expense.

\section{$<$ INSERT TABLE IX ABOUT HERE $>$}

Table IX reports the results of changes in cost of capital, with the unadjusted cost of capital in Panel A and the abnormal cost of capital in Panel B. First, the unadjusted cost of capital significantly declines around the $\mathrm{R} \& \mathrm{D}$ decrease. For example, the mean cost of capital drops from $13.273 \%$ to $10.886 \%$ (difference $=-2.387 \%$, $t$-statistics $=-3.94$ ). After controlling for matching firms, the R\&D-decrease firms significantly reduce their cost of capital (mean =

\footnotetext{
${ }^{16}$ Because R\&D decreases span for one year, we also try skipping one year when estimating the cost of capital to emphasize the difference in risks between before and after R\&D decreases. In particular, we use 60 months from July of year $t-5$ to June of year $t$ as the pre-event period and 60 months from July of year $t+1$ to June of year $t+6$ as the post-event period to run regression model (2). Although not reported here, the results are qualitatively similar.
} 
$-2.443 \%, t$-statistics $=-2.36$; median $=2.099 \%, p$-value $=0.045) .{ }^{17}$ These results are consistent with the overinvestment story that R\&D decreases are followed by a reduction in cost of capital.

\section{E. Regression Analysis}

The results presented thus far are consistent with the overinvestment hypothesis but not the spillover or myopia hypothesis. As a final check, we perform Fama-MacBeth (1973) cross-sectional regressions to test the three hypotheses. The dependent variable is the monthly raw return. Monthly regressions are carried out from July 1976 to December 2006. The control variables (except momentum, which is updated monthly) are updated annually in June of year $y+1$ or at the fiscal year end of year $y$ and used in the following 12 monthly regressions (from July of year $y+1$ to June of year $y+2)$ to control for the anomalies reported in the asset pricing literature. See the Appendix for detailed definitions of these variables.

To test the three hypotheses, we include following variables in the regressions. $L D R D$ is equal to 1 if the firm has a large decrease in $R \& D$ expenditures in any year during year $y-5$ to year $y$, and zero elsewhere. $R \& D$ dummy is equal to 1 if the $R \& D$ expense at the fiscal year-end of year $y$ is missing, and zero elsewhere. Using this R\&D dummy allows us to include firms without R\&D information in Compustat and thus increase the power of tests. $R \& D$ follower is a dummy variable that is equal to 1 if the firm's $R \& D$ is below its industry median (based on three-digit SIC as the industry classification) during fiscal year $y$. $R \& D$ follower(b)* $L D R D$ is equal to 1 if the firm is classified as a R\&D-decrease firm during year $y-5$ to year $y$ and its R\&D is below the industry median at the beginning of the R\&D-decrease year, and zero otherwise. ${ }^{18}$

\footnotetext{
17 To check the robustness of results, we also performed the calendar-time approach by first calculating the averages of cost of capital each year, and then computing the mean and median value of these averages across years. The results are qualitatively similar to what we report here. We do not show these calendar-time results to save space.

${ }^{18}$ The $b$ within the parenthesis in the variable denotes the timing of measuring the variable at the beginning of R\&D decreases.
} 
The institutional ownership is defined as total shares owned by institutions, obtained from Thomson Reuters $13 f$ database, divided by total shares outstanding. IO dummy is equal to 1 if there is no institutional ownership information from the $13 \mathrm{f}$ database, and zero otherwise. Low $I O$ is a dummy variable that is equal to 1 if the firm's institution ownership is below its industry median at the end of December of year $y$, and zero otherwise. Low $I O(b) * L D R D$ is equal to 1 if it is a R\&D-decrease firm in any year during year $y-5$ to year $y$ and its institution ownership is below the industry median at the beginning of the R\&D-decrease year, and zero otherwise. Low $Q$ is a dummy variable that is equal to 1 if Tobin's $Q$ is below 1 at the end of December of year $y$, and zero otherwise. Low $Q(b) * L D R D$ is equal to 1 if it is a R\&D-decrease firm during year $y-5$ to year $y$ and its Tobin's $\mathrm{Q}$ is below 1 at the beginning of the R\&D-decrease year, and zero otherwise. Decrease $Q$ is a dummy variable that is equal to 1 if Tobin's $Q$ drops more than $10 \%$ from year $y-1$ to year $y$, and zero otherwise. Decrease $Q(b) * L D R D$ is equal to 1 if it is a R\&D-decrease firm during year $y-5$ to year $y$ and its Tobin's Q drops more than $10 \%$ at the beginning of the R\&D-decrease year, and zero otherwise. $\Delta$ Cost of capital is the change in cost of capital obtained from Table IX. The empirical results of Fama-MacBeth (1973) cross-sectional regressions are presented in Table X.

$<$ INSERT TABLE X ABOUT HERE $>$

In Model 1 , we test the R\&D-decrease effect by including the $L D R D$ dummy and firm characteristics. The significantly positive coefficient for the $L D R D$ dummy (coefficient $=0.0027$, $t$-statistics $=4.23)$ is consistent with results in our previous tables. Since we have controlled for various anomaly variables, this result suggests that the return drift of R\&D-decrease firms is not explained by asset pricing anomalies reported in the literature. 
In Model 2, we include the industry dummies to test the spillover hypothesis. We conjecture that if the R\&D spillover effect is obvious in an industry, R\&D-decrease firms in this industry may take advantage of the benefit from R\&D spillovers, and returns of R\&D-decrease firms in this industry could be uniformly high. ${ }^{19}$ As a result, the positive return drift of R\&D-decrease firms might be explained by the industry fixed-effect. However, our empirical result shows that the $L D R D$ is significantly positive even with the control of industries. This result is against the spillover story but consistent with our earlier finding that the R\&D decrease effect survives after careful controls of the potential industry effect (see Table V, Panels D and E). It also suggests that our results are not driven by one or two industries.

In Model 3, we classify sample firms into R\&D leaders and R\&D followers. Lev, Radhakrishnan, and Ciftci (2005) suggest that a R\&D leader, which generally has better techniques, outperforms the R\&D follower. However, if the R\&D spillover effect exists, the $R \& D$ follower that exploits the technology from the R\&D leader via the spillover effect may lower the production cost and gain more benefits. In contrast, the R\&D leaders take less benefit via the R\&D spillover effect from their peers because they have likely already obtained the knowledge or networks of spillovers. Accordingly, the spillover effect suggests that R\&D followers should experience higher abnormal return than R\&D leaders in our sample. The significantly negative coefficient on $R \& D$ follower is consistent with results in Lev, Radhakrishnan, and Ciftci (2005). However, the coefficient of the interacting term of $R \& D$ follower $(b) * L D R D$ is insignificant ( $t$-statistics $=0.66$ ), a finding inconsistent with the spillover

\footnotetext{
${ }^{19}$ Bernstein and Nadiri (1988) use the concept of industry's R\&D capital to investigate the relation between industry's R\&D capital and the social rate of return. In their definition, the social rate of return to an industry's R\&D capital consists of the private rate of cost reductions plus the inter-industry cost reductions due to the spillover effect generated by the industry's R\&D capital. Here the impact of industry's R\&D capital on social rate of return could be represented by the industry fixed-effect. In this paper, we use one-digit SIC codes as industry dummies to control the industry fixed-effect. We also try the industry dummies based on two-digit SIC codes, and the results are qualitatively similar.
} 
story. Overall, the results in Models 2 and 3 do not provide compelling evidence to support the spillover hypothesis.

In Model 4, we test the managerial myopia hypothesis by examining whether the institutional ownership affects stock returns. Because firms with low institutional ownership are more likely to cut R\&D to manipulate earnings (Bushee, 1998; Roychowdhury, 2006), we expect that R\&D-decrease firms with low institutional ownership generate more abnormal returns if the myopia hypothesis is correct. However, we do not find that the R\&D-decrease firms with low institutional ownership perform significantly different (i.e., Low $\operatorname{IO}(b) * L D R D$ is insignificant). This result is consistent with those reported in Table VII and suggests that the managerial myopia hypothesis cannot explain the return drift following R\&D decreases. ${ }^{20}$

In Models 5 and 6, we use Tobin's Q as the proxy for the investment opportunity to test the overinvestment hypothesis. We find that both interacting terms of Low $Q(b) * L D R D$ and Decrease $Q(b) * L D R D$ are significantly positive. This result is consistent with the notion that R\&D-decrease firms with few investment opportunities and with decreases in their growth potentials outperform because they reduce their potential agency costs by removing inefficient projects.

In Model 7, we test whether changes in cost of capital affect stock returns. The interacting term of $L D R D$ and $\triangle$ Cost of capital is -0.0002 ( $t$-statistics $=-2.83$ ). As a result, we find that the more the cost of capital declines, the higher the stock return for R\&D-decrease firms. These

${ }^{20}$ Moreover, recent research suggests that managers may engage in real earnings management by cutting R\&D outlays to avoid earnings losses (Graham, Harvey, and Rajgopal, 2005; Roychowdhury, 2006). Clearly, this conduct is one type of managerial myopic behavior; maintaining the reported earnings at a certain threshold (i.e., positive earnings) through reductions of $R \& D$. If firms doing so, we would expect a performance reversal following $R \& D$ decreases. In unreported model, we test this idea by including into regressions a dummy for sample firms, which equals 1 if earnings at year $t$, the ending year of R\&D decreases, are positive but negative without $R \& D$ decreases (i.e., $\operatorname{EBITDA}(t)>0$ and $\operatorname{EBITDA}(t)+\mathrm{R} \& \mathrm{D}(t)-\mathrm{R} \& \mathrm{D}(t-1)<0)$, and zero otherwise. We find that this dummy variable is insignificant while other variables remain the same. This result further suggests that our findings are not driven by the managerial myopia. 
results help to interpret the overinvestment hypothesis. Specifically, the R\&D-decrease firms cut down R\&D investments thereby avoiding the overinvestment problem and lowering the risk and cost of capital. Because the discount rate becomes smaller, the firm value would be higher, especially for those R\&D-decrease firms with larger reductions in cost of capital. The negative relation between changes in cost of capital and stock returns also suggests that investors do not incorporate changes in cost of capital into pricing at a timely fashion.

Finally, we test three hypotheses simultaneously in Models 8 and 9. Because firms with low Q and firms with decreases in Q are highly correlated, we use a dummy interaction term of Low $Q(b) *$ Decrease $Q(b) * L D R D$ to capture the low $\mathrm{Q}$ and decrease $\mathrm{Q}$ effects in sample firms at the same time. The results are reported in Model 8. The significantly positive coefficient of this dummy indicates that firms with low investment opportunities and decreases in growth potentials do enjoy better returns following large R\&D reductions. Meanwhile, the interaction terms of $R D$ follower $(b) * L D R D$ and $L o w I O(b) * L D R D$ remain insignificant. These results confirm that our findings are most consistent with the overinvestment hypothesis but inconsistent with the R\&D spillover and managerial myopia hypotheses. To combine the low Q, decrease Q, and cost of capital effects in our sample, we define Decrease in cost of capital as the change in cost of capital if the cost of capital decreases around R\&D reductions and zero otherwise, and interact it with the dummy term of Low $Q(b) *$ Decrease $Q(b) * L D R D$. In Model 9, the significantly negative coefficient of this interaction term suggests that for firms with a decline in growth potentials and a low investment opportunity, the more decrease in cost of capital after R\&D reductions, the better the future stock performance. This result is consistent with previous models and indicates the market inability to predict the decrease in cost of capital of R\&D-decrease firms. 
We perform several additional models in this Fama-MacBeth (1973) regression test. For example, we include into regressions the R\&D capital, measured by Chan, Lakonishok, and Sougiannis (2001), instead of the R\&D expense as the control variable. We also incorporate the R\&D increase dummy and an interaction term over $L D R D$ and prior R\&D increase dummy (i.e., control for the R\&D increase effect in stock universe and for the effect that R\&D-decrease firms that experienced significant $R \& D$ increases before cutting $R \& D$ expenses). Moreover, to further test whether our results are driven by return reversals, we add into the regression raw buy-and-hold returns (either three-year or five-year) prior to the firm being selected as a sample firm. Finally, we drop the repurchase firms from the regression models. None of these additional controls affect our results, and the coefficient of $L D R D$ remains significantly positive.

\section{Conclusion}

The literature is rich in reporting that R\&D investments enhance shareholder value. However, very few extant papers examine the valuation and impact of R\&D decreases. This paper adds to the literature by investigating the stock returns following R\&D decreases. Because past research shows a positive relation between $R \& D$ expenditures and future stock returns, conventional wisdom suggests a negative signal for R\&D decreases. Contrary to this traditional view, using data from 1975 to 2005, we find that firms with a large decline in their R\&D expenditures earn significantly positive abnormal returns in the long run. We control for various return anomaly variables, and our results remain significant. Furthermore, we find that our results are not driven by the R\&D increase effect (Eberhart, Maxwell, and Siddique, 2004), the R\&D level effect (Lev and Sougiannis, 1996; Chan, Lakonishok, and Sougiannis, 2001), or the capital expenditures effect (Titman, Wei, and Xie, 2004). In addition, we show that the return drift of share repurchase firms, which also experience R\&D reductions (Grullon and Michaely, 
2004), cannot account for our results. Finally, we control for the industry effect and find that our results are not driven by specific industries. We conclude that large $R \& D$ decreases enhance, rather than destroy, shareholder value.

We explore three potential economic motives behind R\&D reductions-spillover, managerial myopia, and overinvestment-to identify sources of return predictability of R\&D decreases and understand why managers cut R\&D spending. We do not find support for the spillover hypothesis, which predicts an improving subsequent performance, especially for R\&D followers. In particular, firms with large R\&D reductions experience poor earnings right before $R \& D$ decreases but no abnormal pattern thereafter, and $R \& D$ followers do not outperform $R \& D$ leaders in our sample. In testing the managerial myopia story, we do not find an evident reversal pattern in subsequent firm performance for firms with large $R \& D$ reductions or for their subset of firms with low institutional ownership. As a result, we find little evidence to support the myopia hypothesis.

Our results are most consistent with the overinvestment explanation. We find that the market anticipates poorer earnings right before the R\&D decreases, suggesting deteriorating fundamentals and investment opportunities. R\&D reductions are followed by a decrease in costs of capital. Although these firms face smaller options to grow, their returns are higher, especially for firms with low investment opportunities, with reductions in growth potentials, and with decreased cost of capital. All these results, along with the evidence of poor operating performance immediately preceding $R \& D$ decreases, are consistent with the overinvestment hypothesis, which suggests that firms experiencing a shrinking investment set reduce their $R \& D$ intensity to avoid the empire-building and overinvestment problems. 
Overall, we show, contrary to conventional wisdom, that significant R\&D reductions enhance shareholder value. However, investors may underestimate the magnitude of improvement in cost of capital (Grullon and Michaely, 2004) and the reduction in agency costs. We provide evidence to support Daniel and Titman's (2006) finding that intangible information is related to future stock returns and offer a potential reason (i.e., mis-estimation of changes in cost of capital) why future returns are related to intangible information.

We offer two caveats to our results. First, although we do not find evidence that the myopia hypothesis explains the return drift following R\&D decreases, we do not claim that the managerial myopic behavior on R\&D does not exist. Previous research finds that managers may execute earnings management to discretionarily reduce R\&D investments for short-term benefits (Bushee, 1998; Graham, Harvey, and Rajgopal, 2005). We find, however, that when firms significantly reduce their $R \& D$, these decreases in $R \& D$ are more likely to be driven by the intent to alleviate the overinvestment problem rather by managerial myopia. Second, even though we show that the returns following R\&D decreases are related to changes in cost of capital and the mitigation of overinvestment problems, why investors do not anticipate the decreases in cost of capital and incorporate the reduction in agency costs into pricing in a timely fashion is not clear. We leave this question to future research. 


\section{References}

Aboody, David, and Baruch Lev, 2000, Information asymmetry, R\&D, and insider gains, Journal of Finance 55, 2757-2766.

Barber, Brad M., and John D. Lyon, 1996, Detecting abnormal operating performance: The empirical power and specification of test statistics, Journal of Financial Economics 41, 359-399.

Berk, Jonathan B., Richard C. Green, and Vasant Naik, 1999, Optimal investment, growth options, and security returns, Journal of Finance 54, 1553-1607.

Berk, Jonathan B., Richard C. Green, and Vasant Naik, 2004, Valuation and return dynamics of new ventures, Review of Financial Studies 17, 1-35.

Bernstein, Jeffrey I., and M. Ishaq Nadiri, 1988, Interindustry R\&D spillovers, rates of return, and production in high-tech industries, American Economic Review 78, 429-434.

Brav, Alon, 2000. Inference in long-horizon event studies: A Bayesian approach with application to initial public offerings, Journal of Finance 55, 1979-2016.

Brav, Alon, Christopher Geczy, and Paul A. Gompers, 2000, Is the abnormal return following equity issuances anomalous? Journal of Financial Economics 56, 403-416.

Brous, Peter A., and Omesh Kini, 1993, A reexamination of analysts’ earnings forecasts for takeover targets, Journal of Financial Economics 33, 201-225.

Bushee, Brain J., 1998, The influence of institutional investors on myopic R\&D investment behavior, Accounting Review 73, 305-333.

Carhart, Mark M., 1997, On persistence in mutual fund performance, Journal of Finance 52, 57-82.

Carlson, Murray, Adlai Fisher, and Ron Giammarino, 2004, Corporate investment and asset pricing dynamics: Implications for the cross-sectional of returns, Journal of Finance 59, 2577-2603.

Chan, Konan., Louis K. C. Chan, Narasimhan Jegadeesh, and Josef Lakonishok, 2006, Earnings quality and stock returns, Journal of Business 79, 1041-1082. 
Chan, Louis K. C., Josef Lakonishok, and Theodore Sougiannis, 2001, The stock market valuation of research and development expenditures, Journal of Finance 56, 2431-2456.

Chan, Su Han, John D. Martin, and John W. Kensinger, 1990, Corporate research and expenditures and share value, Journal of Financial Economics 26, 255-276.

Chauvin, Keith W., and Mark Hirschey, 1993, Advertising, R\&D expenditures and the market value of the firm, Financial Management 22, 128-140.

Cooper, Michael J., Huseyin Gulen, and Michael J. Schill, 2008, Asset growth and the cross-section of stock returns, Journal of Finance 63, 1609-1651.

Daniel, Kent D., and Sheridan Titman, 2006, Market reactions to tangible and intangible information, Journal of Finance 61, 1605-1643.

De Bondt, Werner F. M., and Richard H. Thaler, 1985, Does the stock market overreact? Journal of Finance 40, 793-805.

De Bondt, Werner F. M., and Richard H. Thaler, 1987, Further evidence on investor overreaction and stock market seasonality, Journal of Finance 42, 557-581.

Eberhart, Allan C., William F. Maxwell, and Akhtar R. Siddique, 2004, An examination of long-term abnormal stock returns and operating performance following $R \& D$ increases, Journal of Finance 59, 623-650.

Fama, Eugene F., 1998, Market efficiency, long-term returns, and behavioral finance, Journal of Financial Economics 49, 283-306.

Fama, Eugene F., and Kenneth R. French, 1998, Taxes, financing decisions, and firm value, Journal of Finance 53, 819-843.

Fama, Eugene F., and Kenneth R. French, 2000, Forecasting profitability and earnings, Journal of Business 73, 161-175.

Fama, Eugene F., and Kenneth R. French, 2008, Dissecting anomalies, Journal of Finance 63, 1653-1678.

Fama, Eugene F., and James D. MacBeth, 1973, Risk, return and equilibrium: Empirical tests, Journal of Political Economy 81, 607-636. 
Graham, John R., Campbell R. Harvey, and Shiva Rajgopal, 2005, The economic implications of corporate financial reporting, Journal of Accounting and Economics 40, 3-73.

Griliches, Zvi, 1979, Issues in assessing the contribution of research and development of productivity growth, Bell Journal of Economics 10, 92-116.

Grullon, Gustavo, and Roni Michaely, 2004, The information content of share repurchase programs, Journal of Finance 59, 651-680.

Hall, Bronwyn H., 1993a, Industrial Research during the 1980s: Did the rate of return fall? Brookings Paper: Microeconomics 2, 289-330.

Hall, Bronwyn H., 1993b, The stock market valuation of R\&D investment during the 1980s, American Economic Review 83, 259-264.

Hertzel, Michael, Michael Lemmon, James S. Linck, and Lynn Rees, 2002, Long-run performance following private placements of equity, Journal of Finance 57, 2595-2617.

Hirschey, Mark, and Jerry J. Weygandt, 1985, Amortization policy for advertising and research and development expenditures, Journal of Accounting Research 23, 326-335.

Hirshleifer, David, Kewei Hou, Siew Hong Teoh, and Yinglei Zhang, 2004, Do investors overvalue firms with bloated balance sheets? Journal of Accounting and Economics 38, 297-331.

Hsu, Po-Hsuan, 2009, Technological innovations and aggregate risk premiums, Journal of Financial Economics 94, 264-279.

Hunt, Robert M., 2006, When do more patents reduce R\&D? American Economics Review 96, 87-91.

Ikenberry, David, Josef Lakonishok, and Theo Vermaelen, 1995, Market underreaction to open market share repurchases, Journal of Financial Economics 39, 181-208.

Jaffe, Adam B., 1986, Technological opportunity and spillovers of R\&D: Evidence from firms’ parents, profits, and market value, American Economic Review 76, 984-1001.

Jensen, Michael C., 1986, Agency costs of free cash flow, corporate finance, and takeovers, American Economic Review 76, 323-329. 
Lev, Baruch, Suresh Radhakrishnan, and Mustafa Ciftci, 2005, The stock market valuation of R\&D leaders, Working paper, New York University.

Lev, Baruch, Bharat Sarath, and Theodore Sougiannis, 2005, R\&D reporting biases and their consequences, Contemporary Accounting Research 4, 977-1026.

Lev, Baruch, and Theodore Sougiannis, 1996, The capitalization, amortization and value-relevance of R\&D, Journal of Accounting and Economics 21, 107-138.

Loughran, Tim, and Jay R. Ritter, 1995, The new issue puzzle, Journal of Finance 50, 23-51.

Loughran, Tim, and Jay R. Ritter, 1996, Long-term market overreaction: The effect of low-priced stocks, Journal of Finance 51, 1959-1970.

Loughran, Tim, and Jay R. Ritter, 2000, Uniformly least powerful tests of market efficiency, Journal of Financial Economics 55, 361-389.

Loughran, Tim, and Anand M. Vijh, 1997, Do long-term shareholders benefit from corporate acquisitions? Journal of Finance 52, 1765-1790

Lyon, John D., Brad M. Barber, and Chih-Ling Tsai, 1999, Improved methods for test of long-run abnormal stock returns, Journal of Finance 54, 165-201.

Megna, Pamela, and Mark Klock, M., 1993, The impact of intangible capital on Tobin’s q in the semiconductor industry, American Economic Review 83, 265-269.

Meulbroek, Lisa K., Mark L. Mitchell, J. Harold Mulherin, Jeffry M. Netter, and Annette B. Poulsen, 1990, Shark repellents and managerial myopia: An empirical test, Journal of Political Economy 98, 1108-1117.

Mitchell, Mark L., and Erik Stafford, 2000, Managerial decisions and long-term stock price performance, Journal of Business 73, 287-329.

Newey, Whitney K., and Kenneth D. West, 1987, A simple, positive semi-definite, heteroskedasticity and autocorrelation consistent covariance matrix, Econometrica 55, 703-708.

Pastor, Lubos, and Robert F. Stambaugh, 2003, Liquidity risk and expected stock returns, Journal of Political Economy 111, 642-685. 
Penman, Stephen H., and Xiao-Jun Zhang, 2002, Accounting conservatism, the quality of earnings, and stock returns, Accounting Review 77, 237-264.

Pontiff, Jeffrey, and Artemiza Woodgate, 2008, Share issuance and cross-sectional returns, Journal of Finance 63, 921-945.

Ritter, Jay R., 1991, The long-run performance of initial public offerings, Journal of Finance 46, $1-27$.

Roychowdhury, Sugata, 2006, Earnings management through real activities manipulation, Journal of Accounting and Economics 42, 335-370.

Shumway, Tyler, 1997, The delisting bias in CRSP data, Journal of Finance 52, 327-340.

Shumway, Tyler, and Vincent A. Warther, 1999, The delisting bias in CRSP's Nasdaq data and its implications for the size effect, Journal of Finance 54, 2361-2379.

Sloan, Richard G., 1996, Do stock prices fully reflect information in accruals and cash flows about future earnings? Accounting Review 71, 289-315.

Spiess, D. Katherine, and John Affleck-Graves, 1999, The long-run performance of stock returns following debt offerings, Journal of Financial Economics 54, 45-73.

Stein, Jeremy C., 1989, Efficient capital markets, inefficient firms: A model of myopic corporate behavior, Quarterly Journal of Economics 104, 655-669.

Szewczyk, Samuel H., George P. Tsetsekos, and Zaher Zantout, 1996, The valuation of corporate R\&D expenditures: Evidence from investment opportunities and free cash flow, Financial Management 25, 105-110.

Titman, Sheridan, K. C. John Wei, and Feixue Xie, 2004, Capital investments and stock returns, Journal of Financial and Quantitative Analysis 39, 677-700.

White, Halbert, 1980, Heteroskedasticity-consistent covariance matrix and a direct test for heteroskedasticity? Econometrica 48, 817-838. 


\section{Appendix}

\section{A. Variable Definition}

To run calendar-time portfolio regressions for the period of July of year $y+1$ to June of year $y+2$, we follow the literature to define the anomaly variables stated in the following discussion.

- Asset growth is the annual firm asset growth rate, defined as [asset $(y)$ - asset $(y-1)$ ]/asset $(y-1)$, where asset is the total assets (Compustat data item 6).

- Net share issue is the annual share issuance, defined as natural log of the ratio of split-adjusted shares outstanding at the end of December of year $y$ to split-adjusted shares outstanding at the end of December of year $y-1$, where the split-adjusted shares outstanding equal to CRSP shares outstanding divided by cumulative total factor to adjust shares outstanding from CRSP.

- Accruals are the change in noncash working capital minus depreciation (Compustat data item 14) at the fiscal year end of year $y$, where noncash working capital is current assets (item 4) minus cash (item 1) minus current liabilities (item 5) plus debt in current liabilities (item 34) plus taxes payable (item 71), all scaled by the average of total assets (item 6) at the fiscal year-end of years $y$ and $y-1$.

- Net operating assets are the operating assets minus operating liabilities at the fiscal year-end of year $y$, where the operating assets are total assets (Compustat item 6) minus cash (item 1), and the operating liabilities are total assets minus debt included in current liabilities (item 34), minus long-term debt (item 9), minus minority interests (item 38), minus preferred stocks (item 130), and minus common equity (item 60), all scaled by lagged total assets at the fiscal year-end of year $y-1$.

- Liquidity is the turnover ratio, defined as monthly trading volume at the end of June of year $y+1$ divided by the outstanding shares at the end of June of year $y+1$.

- Capital expenditure is abnormal capital expenditure, defined as the ratio of capital expenditure (Compustat data item 128) to sales (item 12) at the fiscal year-end of year $y$ divided by the average ratio of capital expenditure to sales over previous three years, $y-3$ to $y-1$, and then minus 1 . 
- $R \& D$ is the $R \& D$ intensity, defined as research and development expenditure (Compustat data item 46) at fiscal year-end of year $y$ divided by the average of total assets (item 6) at the fiscal year-end of years $y-1$ and $y$.

We also use these anomaly variables to form additional factors and add into equation (1). The factor-mimicking portfolios are constructed as follows. On the end of June of year $y+1$, we sort stocks independently into quintiles based on each of previously defined anomaly variables. We then compute the monthly value-weighted returns for extreme quintiles for each sort from July of year $y+1$ to June of year $y+2$. The difference in returns between extreme quintiles is the factor-mimicking portfolio return. For example, the asset growth factor return is the return of low asset growth quintile minus the return of high asset growth quintile. The factors of net share issue, accruals, net operating assets, liquidity, and capital expenditure are constructed in the same fashion. The $R \& D$ factor return is the high $R \& D$ quintile return minus low $R \& D$ quintile return. Each of these factors is added separately into the Carhart (1997) four-factor model (equation 1) to form a five-factor model.

In addition to the anomaly variables, we also control for the following variables in the Fama-MacBeth (1973) regressions. These variables (except momentum, which is updated monthly) are measured on June of year $y+1$ or at the year-end of fiscal year $y$ and used for regressions from July of year $y+1$ to June of year $y+2$.

- Size is the natural logarithm of market value of equity, defined as the number of shares outstanding times price per share at the end of June of year $y+1$.

- $B M$ is the book-to-market, defined as the book value of equity (Compustat item 60) at the fiscal year-end of year $y$, divided by market value of equity at the end of June of year $y+1$.

- Momentum is the prior 11-month cumulative return from month $\tau-12$ to month $\tau-2$, where $\tau$ is the month that regressions are performed.

- Net share issue dummy is equal to 1 if the net share issue is not available, and zero otherwise.

- Capital expenditure dummy is equal to 1 if the abnormal capital expenditure is not available, and zero otherwise. 


\section{B. Buy-and-Hold Returns and Average Monthly Returns}

For buy-and-hold returns, we compound monthly returns from July of year $t+1$ for 60 months for each sample observation, where year $t$ is the ending year of R\&D decreases. This implicitly assumes a six-month reporting lag when we form a R\&D-decrease portfolio. We compute the mean portfolio return for each cohort year and then average these mean returns across time. Here, the last cohort year is 2000 (where buy-and-hold returns are compounded from July 2001 to June 2006) to ensure that returns in the full five-year horizon are tracked. Regarding the average monthly returns, we first calculate the mean monthly portfolio returns over a 60 -month horizon from July of year $t+1$ and then average these mean monthly portfolio returns across cohort years. To measure abnormal returns for both buy-and-hold and average monthly return approaches, we choose control firms matched on size, book-to-market, and momentum. Specifically, in each June-end of year $t+1$, we independently sort all NYSE firms into three groups (30-40-30) based on market capitalization, book-to-market, and prior one-year return (excluding June of year $t+1$ ), respectively. We then classify each firm in the stock universe into one of 27 size/book-to-market/momentum portfolios. For each sample firm, we search for the control firm within the same size/book-to-market/momentum portfolio and with the closest book-to-market ratio as of the sample firm. The abnormal returns are obtained by subtracting matching firm returns from sample firm returns.

\section{Abnormal Operating Performance}

To compute abnormal ROA, we identify a control firm for a given sample firm from all potential matching firms (i.e., nonsample firm-year observations) with the same two-digit SIC code. We choose the control firm with the closest pre-event ROA at year $t-1$ (the beginning year of $\mathrm{R} \& \mathrm{D}$ decreases) and $\mathrm{R} \& \mathrm{D}$-to-asset ratio at year $t$ (the ending year of $\mathrm{R} \& \mathrm{D}$ decreases) as of the sample firm. We require that the control firm's ROA at year $t-1$ and R\&D ratio at year $t$ are within the $(90 \%, 110 \%)$ range as of the sample firm. As ROAs or R\&D ratios for some sample

firms are too small, the filter as defined might be too restrictive to identify a matching firm. In such situation, we require $R \& D$ ratio and pre-event ROA are within \pm 0.01 range of the sample firm. If any sample firm is not matched according to this definition, we relax the industry requirement to the one-digit SIC and then repeat the step. If this again does not find the control 
firm, we disregard industry requirement and search for the matching firm, with the closest R\&D ratio and pre-event ROA, which satisfies the $(90 \%, 110 \%)$ filter. If we still do not have a match at this point, we simply identify one firm with the closest R\&D ratio and pre-event ROA as of the sample firm based on the following criterion:

$$
\min \left|R O A_{\text {sample firm, } \mathrm{t}-1}-R O A_{\text {sample firm, } \mathrm{t}-1}\right|+\left|R D_{\text {sample firm, } \mathrm{t}}-R D_{\text {matching firm }, \mathrm{t}}\right| \text {. }
$$


Table I

\section{Summary Statistics}

This table reports the summary statistics for sample firms. The initial sample comprises stocks that are covered on both Compustat and CRSP databases with available research and development expenditures (Compustat annual data item 46). We consider only domestic common stocks and exclude closed-end funds, investment trusts, units, and foreign companies. In each year $t$ from 1975 to 2005, our sample firms are required to have (a) the $R \& D$ intensity, the ratio of $R \& D$ expenditure to total assets, of at least $5 \%$ in year $t-1$ and (b) the Change in $R \& D$, the difference in $\mathrm{R} \& \mathrm{D}$ expenditures in years $t-1$ and $t$ divided by total assets in year $t-1$ to be negative with an absolute value more than 3\% (i.e., R\&D expenditures drop more than 3\% of the lagged total assets). Panel A reports the firm-year observations across years and industries based on one-digit SIC code. Panel B reports firm characteristics of sample observations. $R \& D$ growth rate measures the growth in $R \& D$ expenditures from year $t-1$ to year $t$. Change in $R \& D$ intensity is the difference in the R\&D intensity ratios (i.e., $R \& D /$ Assets) between year $t-1$ and year $t$. $R \& D$ intensity after $R \& D$ decreases is the ratio of $R \& D /$ Assets measured at year $t$. Size is the market value of equity and is measured at the June-end of year $t+1$. Book-to-market is the book value of equity (item 60) at year $t$ divided by Size. Size decile and Book-to-market quintile use the cutoffs based on NYSE firms only. Tobin's $Q$ is the market value of assets (size plus book value of assets minus book value of equity) divided by the book value of assets. Assets (sales) growth is the annual growth rate of the total assets (sales). Accruals is the total accruals defined as the change in non-cash current assets (item 4 - item 1), minus the change in current liabilities excluding short-term debt and taxes payable (item 34 - item 5 - item 71), minus depreciation (item 14), and then scaled by average total assets (see Sloan, 1996). Abnormal capital expenditure is the ratio of capital expenditure (item 128) to sales divided by the average ratio of capital expenditure to sales over prior three years (see Titman, Wei, and Xie, 2004) and then subtracts 1 . All accounting numbers are measured at year $t$, the ending year of R\&D decreases. Assets, sales, and size are expressed in million dollars and adjusted by the CPI to reflect 2005 dollars. The mean numbers in Panel B are with top and bottom $1 \%$ winsorization.

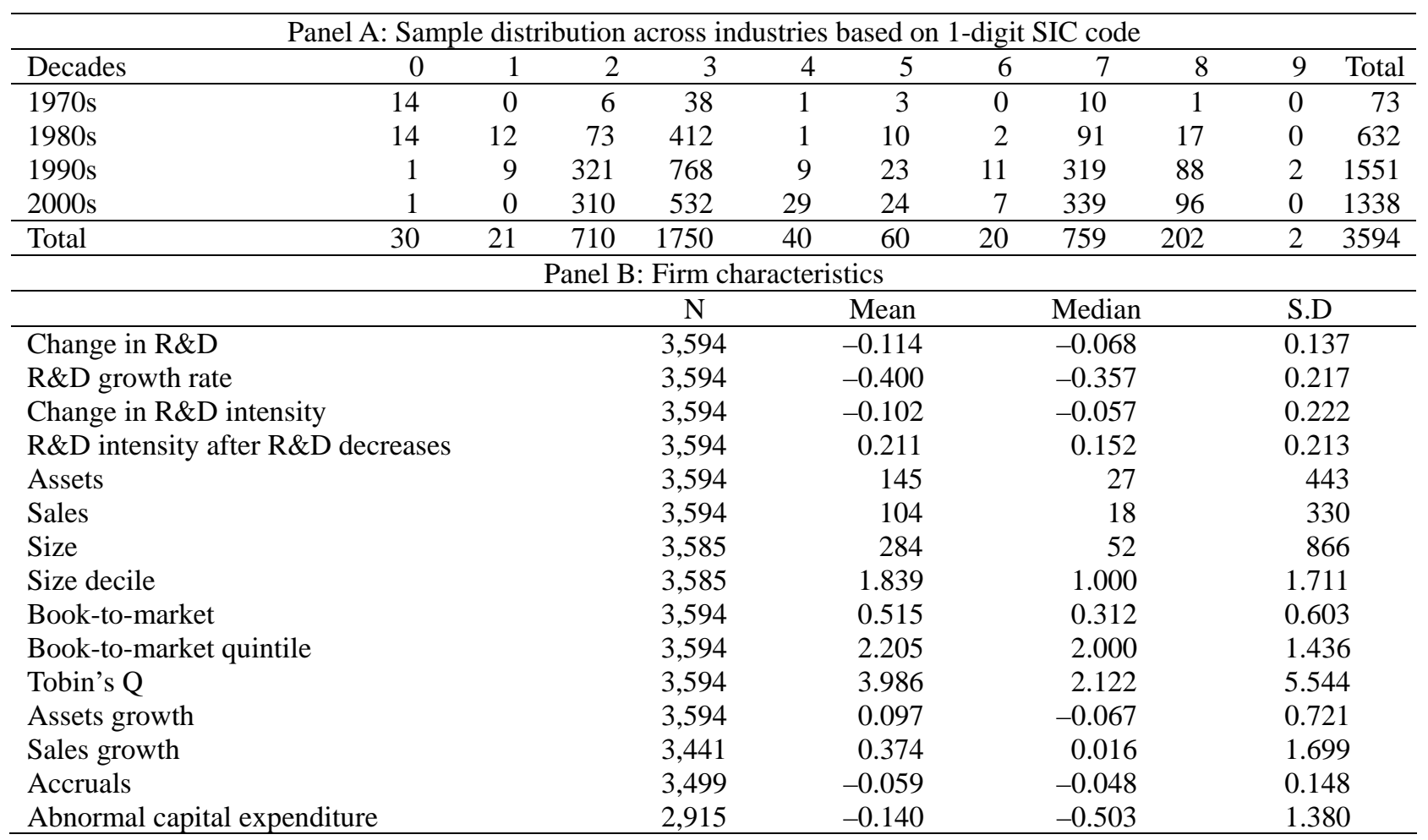




\section{Table II}

\section{Time-Series of R\&D Change and Firm Growth around R\&D Decreases}

In each year $t$ from 1975 to 2005, our sample firms are required to have (1) the $R \& D$ intensity, the ratio of R\&D expenditure to total assets, of at least $5 \%$ in year $t-1$ and (2) the Change in $R \& D$, the difference in $R \& D$ expenditures in years $t-1$ and $t$ divided by total assets in year $t-1$, to be negative with an absolute value more than $3 \%$ (i.e., R\&D expenditures drop more than 3\% of the lagged total assets). Tobin's $\mathrm{Q}$ is defined as the market value of equity plus the book value of debt, then divided by book value of equity. This table reports the time-series of R\&D intensity, change in R\&D, R\&D growth rate, assets growth and sales growth of sample firms in the five years before and five years after year $t$ (labeled as year 0 in the table), the ending year of large $R \& D$ decreases. $R \& D$ growth, Assets growth and sales growth are the annual growth rates of R\&D, total assets and sales, respectively.

\begin{tabular}{|c|c|c|c|c|c|c|c|c|c|c|c|c|}
\hline \multirow{2}{*}{$\begin{array}{c}\text { Event } \\
\text { Year }\end{array}$} & \multicolumn{2}{|c|}{$\mathrm{R} \& \mathrm{D}$ intensity } & \multicolumn{2}{|c|}{ Change in $\mathrm{R} \& \mathrm{D}$} & \multicolumn{2}{|c|}{ R\&D growth } & \multicolumn{2}{|c|}{ Tobin’s Q } & \multicolumn{2}{|c|}{ Assets growth } & \multicolumn{2}{|c|}{ Sales growth } \\
\hline & Mean & Median & Mean & Mean & Median & Median & Mean & Median & Mean & Median & Mean & Median \\
\hline-5 & 0.216 & 0.149 & 0.094 & 0.027 & 0.535 & 0.249 & 4.674 & 2.492 & 0.843 & 0.133 & 0.888 & 0.182 \\
\hline-4 & 0.221 & & & & & & 120 & & 1 & 131 & & 182 \\
\hline-3 & 227 & & 20 & & 589 & & 712 & 31 & 1.318 & .123 & 86 & 186 \\
\hline-2 & 243 & 174 & 100 & 030 & 0.626 & & 3.473 & & 0.878 & 0.050 & 0.865 & 0.130 \\
\hline-1 & 313 & 0.226 & 0.079 & 0.020 & 0.711 & 126 & 3.313 & 1.844 & 0.171 & -0.107 & 0.558 & 0.032 \\
\hline 0 & & & -0.114 & -0.068 & -0.400 & - 3 & 3.986 & 2 & 0.097 & -0.067 & 0.374 & 16 \\
\hline 1 & & & & & & & 3.856 & 208 & 0.171 & -0.009 & 361 & 070 \\
\hline 2 & & & & & & & 3.584 & 2.205 & & 0.011 & & 086 \\
\hline 3 & & & 14 & 0.007 & 0.194 & & 3.449 & 2.0 & 0.1 & 0.011 & 0.240 & 0.059 \\
\hline 4 & & & & & 205 & & 3.420 & 1 & 0.17 & 0.013 & 31 & 67 \\
\hline 5 & & & 0.014 & 0.007 & 0.222 & 0.089 & 3.199 & 2.095 & 0.197 & 0.032 & 0.218 & 0.072 \\
\hline \multicolumn{13}{|c|}{ Average over event years } \\
\hline$-5 \sim$ & & & & & & & 4.495 & & & & & \\
\hline $1 \sim 5$ & 0.171 & 0.122 & 0.012 & 0.006 & 0.207 & 0.067 & 3.501 & 2.139 & 0.176 & 0.012 & 0.275 & 0.071 \\
\hline
\end{tabular}


Table III

Five-Year Buy-and-Hold Returns and Monthly Returns following R\&D Decreases

This table reports buy-and-hold returns and monthly returns (both in \%) following R\&D decreases. Buy-and-hold return is compounded from July of year $t+1$ for 60 months and monthly return is averaged over 60 months from July of year $t+1$ to June of year $t+6$, where year $t$ is the ending year of R\&D decreases To ensure sample firms have full five-year returns, we only include sample firms up to cohort year 2000 in this table. We compute the mean buy-and-hold returns and monthly returns for each year and then average these mean values over years. The abnormal return is measured based on a control-firm approach. To find the control firm, we first sort NYSE firms into three groups (bottom 30\%, middle $40 \%$, and top 30\%) based on their market value of equity, book-to-market, and prior one-year return (excluding month -1 ), respectively, at each June of year $t+1$. Then all firms in stock universe are assigned into one of the $27(3 \times 3 \times 3)$ portfolios. For each sample firm we choose a control firm within the same size/book-to-market/momentum portfolio as of the sample firm and with the closest book-to-market ratio. The abnormal return is the sample firm portfolio return minus the control firm portfolio return. The numbers in parentheses are $t$-statistics, which are adjusted for the heteroskedasticity and autocorrelation in standard errors by using the Newey-West (1987) method.

\begin{tabular}{lcc}
\hline & Raw return & Abnormal return \\
\hline Buy-and-hold return & 118.17 & 53.66 \\
& $(3.36)$ & $(2.00)$ \\
Monthly return & 2.14 & 0.97 \\
& $(14.94)$ & $(10.39)$ \\
\hline
\end{tabular}


Table IV

Five-Year Abnormal Stock Returns following R\&D Decreases

This table presents the five-year abnormal stock returns (in \%) following R\&D decreases. In each year $t$ from 1975 to 2005, firms are selected into the sample meeting the following requirements: (a) the ratio of R\&D expenditure to total assets is at least $5 \%$ in year $t-1$ and (b) the difference in R\&D expenditures in years $t-1$ and $t$ divided by total assets in year $t-1$ is negative with an absolute value more than $3 \%$ (i.e., R\&D expenditures drop more than $3 \%$ of the lagged total assets). Closed-end funds, investment trusts, units, and foreign companies are excluded from the sample. The abnormal stock return is measured by the alpha in the following Carhart (1997) four-factor regression:

$$
R_{p \tau}-R_{f \tau}=\alpha+\beta\left(R_{m \tau}-R_{f \tau}\right)+s S M B_{\tau}+h H M L_{\tau}+m W M L_{\tau}+\varepsilon_{p \tau},
$$

where $R_{p \tau}$ is the month $\tau$ return of the R\&D-decrease portfolio, $R_{f \tau}$ is the risk-free rate, $R_{m \tau}$ is the CRSP value-weighted market index return, $S M B_{\tau}$ is the small-firm portfolio return minus big-firm portfolio return, $H M L_{\tau}$ is the high book-to-market portfolio return minus low book-to-market portfolio return, and $W M L_{\tau}$ is the past winner portfolio return minus past loser portfolio return. The regression is run from July 1977 to December 2006 and includes firms that have experienced large R\&D decreases in any of the past five years (i.e., month $\tau$ is within 60 months following June of year $t+1$ where year $t$ is the ending year of R\&D decreases). Panel A reports the result for the full sample. Panels B and C show the abnormal returns for the small and large firms, respectively, where small firms are those sample firms with market value of equity at the June-end of year $t+1$ below the sample median. The numbers in parentheses are $p$-values bases on two-tailed $t$-tests, which are adjusted for the heteroskedasticity and autocorrelation in standard errors by using the Newey-West (1987) method. Months with less than 25 stocks in the portfolio are excluded from the regressions. Results are reported for both portfolio weighting schemes, equal weight and log-value weight.

\begin{tabular}{|c|c|c|c|c|c|}
\hline & $\alpha$ & $\beta$ & $s$ & $h$ & $m$ \\
\hline & \multicolumn{5}{|c|}{ Panel A: Full sample } \\
\hline \multirow[t]{2}{*}{ Equal weight } & 1.1417 & 1.0493 & 1.6699 & -0.3909 & -0.3219 \\
\hline & $(0.002)$ & $(0.000)$ & $(0.000)$ & $(0.070)$ & $(0.003)$ \\
\hline \multirow[t]{3}{*}{ Log-value weight } & 0.8910 & 1.0715 & 1.6260 & -0.4072 & -0.2894 \\
\hline & $(0.009)$ & $(0.000)$ & $(0.000)$ & $(0.032)$ & $(0.002)$ \\
\hline & \multicolumn{5}{|c|}{ Panel B: Small Firms } \\
\hline \multirow[t]{2}{*}{ Equal weight } & 1.7267 & 0.9328 & 1.7184 & -0.3495 & -0.3368 \\
\hline & $(0.000)$ & $(0.000)$ & $(0.000)$ & $(0.294)$ & $(0.024)$ \\
\hline \multirow[t]{3}{*}{ Log-value weight } & 1.4696 & 0.9538 & 1.7045 & -0.3615 & -0.3099 \\
\hline & $(0.000)$ & $(0.000)$ & $(0.000)$ & $(0.243)$ & $(0.027)$ \\
\hline & \multicolumn{5}{|c|}{ Panel C: Large Firms } \\
\hline \multirow[t]{2}{*}{ Equal weight } & 0.6829 & 1.1274 & 1.5897 & -0.4573 & -0.3282 \\
\hline & $(0.048)$ & $(0.000)$ & $(0.000)$ & $(0.005)$ & $(0.000)$ \\
\hline \multirow[t]{2}{*}{ Log-value weight } & 0.5449 & 1.1302 & 1.5453 & -0.4673 & -0.2945 \\
\hline & $(0.096)$ & $(0.000)$ & $(0.000)$ & $(0.001)$ & $(0.000)$ \\
\hline
\end{tabular}




\section{Table V \\ Five-Year Abnormal Stock Returns following R\&D Decreases-Robustness Checks}

This table presents robustness checks of five-year abnormal stock returns (in \%) of firms with large decreases in R\&D (i.e., firms with a R\&D-to-asset ratio more than $5 \%$ and with a decrease in R\&D more than $3 \%$ of lagged assets). The abnormal return is measured by the regression alphas based on the Carhart (1997) four-factor model. Panel A and B show various controls of potential biases and risk factors, respectively. Panel C presents results by excluding a specific subset of sample firms. Panel D performs industry controls. Panel E employs a zero-investment portfolio approach by buying R\&D-decrease firms and selling their corresponding matching firms, and then regressing portfolio returns to against factors. In the Rolling-over method row, we estimate the abnormal returns with rolling estimates of factor loadings. In particular, we use the first 60 monthly returns (e.g., from July 1977 to June 1982) of the portfolio to estimate its factor loadings and then calculate the expected portfolio return in month 61 (e.g., July 1982) based on these factor loadings estimated over the previous 60 months multiplied by their corresponding factor returns in month 61. The abnormal return in month 61 is the difference between the actual portfolio return and expected portfolio return. This step is repeated every month, and the number reported here is the time series average of abnormal returns. In the Delisting control row, we follow Shumway (1997) and Shumway and Warther (1999) to correct the delisting bias for firms delisted for performance reasons. In the Five-year sample row, a firm can be included in the sample only once for every five years. In Panel B, we estimate the abnormal stock returns by including an additional risk factor into the Carhart (1997) four-factor model. In the $R \& D$ row, we add the R\&D factor defined as the high R\&D (the level of R\&D expenditure divided by average total assets) quintile return minus the low R\&D quintile return. In the Asset growth row, an asset growth factor, which is the bottom assets-growth quintile return minus the top assets-growth quintile return, is added. In the Net share issue row, the share issuance factor is the return on low net share issuance stocks minus the return on high net share issuance stocks, where the net share issuance is concurrent split-adjusted shares outstanding minus split-adjusted shares in the previous year. In the Net operating assets row, the net operating asset factor is the return on low net operating asset stocks minus the return on high net operating asset stocks, where the net operating assets are noncash assets minus total assets plus debt included in current liabilities, long-term debt, minority interests, preferred stocks, and common equity, all scaled by lagged total assets. In the Accruals row, the accruals factor is the return on bottom accruals quintile minus the return on top accruals quintile. In the Liquidity row, the liquidity factor is the low turnover portfolio return minus the high turnover portfolio return, where the turnover is the monthly trading volume scaled by shares outstanding at the end of June. In the row of Capital expenditure, we add a factor, which is the return difference between two extreme quintiles of abnormal capital expenditure where the abnormal capital expenditure is defined as in Titman, Wei and Xie (2004). In the High R\&D firms row, we delete stocks in the top R\&D-to-assets quartile from the sample. In the Large $R \& D$ increase firms row, we delete stocks that have experienced a large increase in R\&D in any of the past five years, where the large increase in R\&D is defined in Eberhart, Maxwell, and Siddique (2004). In the row of Low capital expenditure firms, we delete firms within the bottom quartile of abnormal capital expenditure based on the Titman, Wei, and Xie (2004) measure. In the Repurchase firms row, we delete firms which make open-market share repurchase announcements, obtained from SDC database and Wall Street Journal index, during the five years before the portfolio formation. In the Target firms row, we drop firms which are the target firms in M\&A transactions obtained from SDC database during the five years after the portfolio formation. In the Adjusting industry medians row, sample firms are selected from high R\&D firms (R\&D intensity more than 5\%) with a decrease in industry-adjusted R\&D more than $3 \%$, where the industry-adjusted R\&D change is the sample firm's change in $R \& D$, defined as dollar amount change in R\&D expenditures divided by total assets, minus industry median of change in R\&D. In Panel E, all matching firms are selected from the nonsample firms that do not have large R\&D decreases in any of the past five years. In the Control industry and ROA row, the matching firm is matched with the same two-digit SIC industry and the closest pre-event (i.e., at the beginning of the R\&D-decrease year) ROA as of the sample firm. In the Control industry, ROA, and R\&D row, a matching firm is selected with the same two-digit SIC industry and the closest sum of pre-event ROA and post-event (i.e., at the ending of the R\&D-decrease year) R\&D intensity as of the sample firm. In the Control size, BM, and momentum row, all firms in stock universe are first sorted into terciles independently by size, book-to-market (BM) and past one-year return (momentum), and a control firm is chosen by matching with the same size/BM/momentum ranking and the closest BM as of the sample firm. Numbers in parentheses are $p$-values bases on two-tailed $t$-tests, which are adjusted for the heteroskedasticity and autocorrelation in standard errors by using the Newey-West (1987) method. Months with less than 25 stocks in the portfolio are excluded from the regression. Results are reported for both portfolio weighting schemes, equal weight and log-value weight. 
Table V (Continued)

\begin{tabular}{|c|c|c|}
\hline & Equal weight & Log-value weight \\
\hline \multicolumn{3}{|c|}{ Panel A: Potential bias control } \\
\hline Rolling-over method & $\begin{array}{c}0.9579 \\
(0.000)\end{array}$ & $\begin{array}{l}0.7390 \\
(0.003)\end{array}$ \\
\hline Delisting control & $\begin{array}{l}1.0808 \\
(0.003)\end{array}$ & $\begin{array}{l}0.8474 \\
(0.011)\end{array}$ \\
\hline Five-year sample & $\begin{array}{r}0.9679 \\
(0.019) \\
\end{array}$ & $\begin{array}{l}0.7869 \\
(0.040)\end{array}$ \\
\hline \multicolumn{3}{|c|}{ Panel B: Include additional factor } \\
\hline Assets growth & $\begin{array}{l}1.1520 \\
(0.003)\end{array}$ & $\begin{array}{l}0.8979 \\
(0.013)\end{array}$ \\
\hline Capital expenditure & $\begin{array}{l}1.1415 \\
(0.002)\end{array}$ & $\begin{array}{l}0.8909 \\
(0.009)\end{array}$ \\
\hline Net share issue & $\begin{array}{l}1.1914 \\
(0.004)\end{array}$ & $\begin{array}{l}0.9324 \\
(0.014)\end{array}$ \\
\hline Net operating assets & $\begin{array}{l}1.1114 \\
(0.003)\end{array}$ & $\begin{array}{c}0.8676 \\
(0.011)\end{array}$ \\
\hline Accruals & $\begin{array}{l}1.0627 \\
(0.003)\end{array}$ & $\begin{array}{l}0.8181 \\
(0.012)\end{array}$ \\
\hline Liquidity & $\begin{array}{l}1.0656 \\
(0.000)\end{array}$ & $\begin{array}{l}0.8176 \\
(0.002)\end{array}$ \\
\hline $\mathrm{R} \& \mathrm{D}$ & $\begin{array}{r}1.0680 \\
(0.002) \\
\end{array}$ & $\begin{array}{l}0.8153 \\
(0.008) \\
\end{array}$ \\
\hline \multicolumn{3}{|c|}{ Panel C: Eliminate specific (extreme) firms } \\
\hline High R\&D firms & $\begin{array}{c}1.1177 \\
(0.003)\end{array}$ & $\begin{array}{l}0.8423 \\
(0.014)\end{array}$ \\
\hline Low capital expenditure firms & $\begin{array}{l}1.0652 \\
(0.007)\end{array}$ & $\begin{array}{l}0.8256 \\
(0.022)\end{array}$ \\
\hline Large R\&D increase firms & $\begin{array}{l}1.0694 \\
(0.009)\end{array}$ & $\begin{array}{l}0.7965 \\
(0.031)\end{array}$ \\
\hline Repurchase firms & $\begin{array}{l}1.1587 \\
(0.001)\end{array}$ & $\begin{array}{l}0.9014 \\
(0.006)\end{array}$ \\
\hline Target firms & $\begin{array}{l}1.1447 \\
(0.003)\end{array}$ & $\begin{array}{l}0.8931 \\
(0.013)\end{array}$ \\
\hline \multicolumn{3}{|c|}{ Panel D: Control industry effects } \\
\hline Adjusting industry medians & $\begin{array}{c}1.1452 \\
(0.002)\end{array}$ & $\begin{array}{l}0.8973 \\
(0.009) \\
\end{array}$ \\
\hline \multicolumn{3}{|c|}{ Panel E: Zero-investment portfolio } \\
\hline Control industry and ROA & $\begin{array}{c}0.5998 \\
(0.000)\end{array}$ & $\begin{array}{l}0.3608 \\
(0.001)\end{array}$ \\
\hline Control industry, ROA and R\&D & $\begin{array}{c}0.4108 \\
(0.001)\end{array}$ & $\begin{array}{l}0.1797 \\
(0.058)\end{array}$ \\
\hline Control size, BM, and momentum & $\begin{array}{l}0.8941 \\
(0.000)\end{array}$ & $\begin{array}{l}0.6958 \\
(0.001)\end{array}$ \\
\hline
\end{tabular}




\section{Table VI}

Operating Performance around R\&D Decreases

This table reports the median operating performance of R\&D-decrease firms. The operating performance is measured by returns on assets (ROA), defined as EBITDA (operating income before depreciation, Compustat annual data item 13) plus after-tax R\&D expenditure divided by average total assets. Panel A reports the raw and abnormal levels of operating performance, and Panel B shows the raw and abnormal changes in operating performance. The abnormal level (change) is the difference between sample firm's ROA level (change) and its matching firm's ROA level (change). The matching firm is searched from the closest ROA level at year -1 (the beginning year of R\&D decreases) and closest R\&D-to-assets at year 0 (the ending year of R\&D decreases) within the same two-digit SIC industry by the following equation:

$$
\text { Min }\left|\mathrm{OP}_{\text {sample firm, }-1}-\mathrm{OP}_{\text {matching firm, }-1}\right|+\left|\mathrm{R} \& \mathrm{D}_{\text {sample firm, } 0}-\mathrm{R} \& \mathrm{D}_{\text {sample firm, } 0}\right| \text {. }
$$

In addition, we require the matching firm to have a prior ROA and R\&D-to-assets within $90 \%$ to $110 \%$ or \pm 0.01 of the sample firm’s prior ROA and R\&D-to-assets. If we cannot find the matching firm in the same two-digit SIC industry, then we search for the one-digit SIC industry. If we still cannot find the matching firm, we search for the matching firm from all listed firms. All numbers are with a top and bottom $1 \%$ truncation. The firms with total assets and sales less then \$3 million are excluded to reduce the impact of extreme outliers.

\begin{tabular}{|c|c|c|c|c|c|c|c|c|c|c|c|}
\hline & Year -5 & Year -4 & Year -3 & Year -2 & Year -1 & Year 0 & Year 1 & Year 2 & Year 3 & Year 4 & Year 5 \\
\hline \multicolumn{12}{|c|}{ Panel A: Levels of ROA } \\
\hline \multirow[t]{2}{*}{ Raw } & 0.0279 & 0.0091 & -0.0102 & -0.0343 & -0.0670 & -0.0406 & -0.0138 & -0.0035 & 0.0101 & 0.0157 & 0.0247 \\
\hline & $(0.063)$ & $(0.004)$ & $(0.000)$ & $(0.000)$ & $(0.000)$ & $(0.000)$ & $(0.000)$ & $(0.000)$ & $(0.731)$ & $(0.084)$ & $(0.000)$ \\
\hline \multirow[t]{2}{*}{ Abnormal } & 0.0090 & 0.0012 & 0.0000 & 0.0056 & -0.0003 & 0.0005 & -0.0013 & -0.0031 & -0.0027 & -0.0011 & 0.0013 \\
\hline & $(0.055)$ & $(0.711)$ & $(0.811)$ & $(0.003)$ & $(0.039)$ & $(0.577)$ & $(0.529)$ & $(0.291)$ & $(0.775)$ & $(0.658)$ & $(0.721)$ \\
\hline \multicolumn{12}{|c|}{ Panel B: Changes in ROA } \\
\hline \multirow[t]{2}{*}{ Raw } & -0.0020 & -0.0060 & -0.0056 & -0.0089 & -0.0199 & 0.0179 & 0.0087 & 0.0034 & -0.0014 & -0.0014 & 0.0015 \\
\hline & $(0.311)$ & $(0.000)$ & $(0.002)$ & $(0.000)$ & $(0.000)$ & $(0.000)$ & $(0.000)$ & $(0.144)$ & $(0.422)$ & $(0.082)$ & $(0.401)$ \\
\hline \multirow[t]{2}{*}{ Abnormal } & 0.0049 & -0.0026 & -0.0002 & 0.0015 & -0.0039 & 0.0025 & 0.0014 & 0.0018 & 0.0035 & -0.0029 & -0.0021 \\
\hline & $(0.192)$ & $(0.233)$ & $(0.851)$ & $(0.392)$ & $(0.031)$ & $(0.481)$ & $(0.284)$ & $(0.955)$ & $(0.260)$ & $(0.010)$ & $(0.901)$ \\
\hline
\end{tabular}


Table VII

Annual Abnormal Stock Returns following R\&D Decreases

This table presents annual abnormal stock returns (in \%) of firms with large decreases in R\&D. Low (high) institutional ownership represents the firm with institutional ownership below (above) the industry median, where institutional ownership is the total shares owned by institutions, obtained from Thomson Reuters 13f database at the beginning of R\&D decreases, divided by total shares outstanding. The abnormal stock return is measured by the alpha in the following Carhart (1997) four-factor regression:

$$
R_{p \tau}-R_{f \tau}=\alpha+\beta\left(R_{m \tau}-R_{f \tau}\right)+s S M B_{\tau}+h H M L_{\tau}+m W M L_{\tau}+\varepsilon_{p \tau},
$$

where $R_{p \tau}$ is the month $\tau$ return of the R\&D-decrease portfolio which includes sample stocks if month $\tau$ is within the $k$-month period ( $k$ ranges from 1 to 60 months) following large R\&D decreases, $R_{f \tau}$ is the risk-free rate, $R_{m \tau}$ is the CRSP value-weighted market index return, $S M B_{\tau}$ is the small-firm portfolio return minus big-firm portfolio return, $H M L_{\tau}$ is the high book-to-market portfolio return minus low book-to-market portfolio return, and $W M L_{\tau}$ is the past winner portfolio return minus past loser portfolio return. The regression alphas in both equal-weighted and value-weighted portfolios are reported. Numbers in parentheses are $p$-values based on two-tailed $t$-tests, which are adjusted for the heteroskedasticity and autocorrelation in standard errors by using the Newey-West (1987) method. $* * *$, **, and $*$ represent the significance levels of $1 \%, 5 \%$, and $10 \%$. Months with less than five stocks in the portfolio are excluded from the regression.

\begin{tabular}{|c|c|c|c|c|c|c|}
\hline \multirow[b]{2}{*}{$\begin{array}{l}\text { Period following } \\
\text { R\&D decreases }\end{array}$} & \multicolumn{2}{|c|}{ Full sample } & \multicolumn{2}{|c|}{ Low institutional ownership } & \multicolumn{2}{|c|}{ High institutional ownership } \\
\hline & $\begin{array}{c}\text { Equal } \\
\text { weight }\end{array}$ & $\begin{array}{l}\text { Log-value } \\
\text { weight }\end{array}$ & $\begin{array}{l}\text { Equal } \\
\text { weight }\end{array}$ & $\begin{array}{l}\text { Log-value } \\
\text { weight }\end{array}$ & $\begin{array}{c}\text { Equal } \\
\text { weight }\end{array}$ & $\begin{array}{l}\text { Log-value } \\
\text { weight }\end{array}$ \\
\hline Months 1-12 & $1.2168^{* *}$ & $1.0099^{* *}$ & $1.4284^{* *}$ & $1.2989^{* *}$ & $1.6667^{* * *}$ & $1.4926^{* * *}$ \\
\hline Months 13-24 & $1.1987^{* *}$ & $0.9261^{*}$ & $1.4795^{* *}$ & $1.3107^{* *}$ & $1.2504^{* * *}$ & $1.0235^{* * *}$ \\
\hline Months 25-36 & $1.2523^{* * *}$ & $1.0075^{* *}$ & $1.0974^{*}$ & 0.9109 & $0.9895^{* *}$ & $0.8306^{* *}$ \\
\hline Months 37-48 & $1.0323^{* *}$ & $0.8040^{*}$ & $1.5563^{* * *}$ & $1.4671^{* * *}$ & $1.2325^{* *}$ & $1.0102^{* *}$ \\
\hline Months 49-60 & $1.1442^{* *}$ & $0.9491^{* *}$ & 0.8063 & 0.7489 & $1.2144^{*}$ & $1.1844^{*}$ \\
\hline Months 1-60 & $1.1417^{* * *}$ & $0.8910^{* * *}$ & $1.0248^{* *}$ & $0.8940^{*}$ & $1.2980^{* * *}$ & $1.1188^{* * *}$ \\
\hline
\end{tabular}


Table VIII

Regressions of Analysts' Forecast Revisions

This table shows the regressions for analysts' forecast revisions on one-year-ahead earnings-per-share for all firms covered on the IBES database. For each firm in the stock universe, we track 72 monthly abnormal forecast revisions around each fiscal year $t$ as the dependent variable, where the abnormal forecast revision is measured by Brous and Kini (1993). $L D R D$ is equal to 1 if the firm is with a R\&D-to-asset ratio of more than $5 \%$ in year $t-1$ and with a decrease in R\&D from year $t-1$ to year $t$ of more than $3 \%$ of lagged total assets, and zero otherwise. $L D R D^{*} F R(-1)$ is equal to 1 if the firm has a large decrease in R\&D (i.e., being selected as a sample firm) between years $t-1$ and $t$ and the forecasts revisions are made during year $t-1$ (the year prior to large $\mathrm{R} \& \mathrm{D}$ decreases), and zero otherwise. $L D R D^{*} F R(-2), L D R D^{*} F R(-3)$, and so on are defined similarly. Size is the log market value of equity in millions, $B M$ is the book-to-market, and Momentum is the 11-month prior buy-and-hold return. $R \& D$ is the research and development expenditure divided by total assets. The numbers in parentheses are $t$-statistics adjusted for the heteroskedasticity by using the White (1980) method.

\begin{tabular}{lcc}
\hline Model & 1 & 2 \\
\hline Intercept & -1.380 & -1.832 \\
LDRD & $(-2.26)$ & $(-2.60)$ \\
& -2.070 & \\
LDRD*FR(-3) & $\mathbf{( - 3 . 1 7 )}$ & 2.846 \\
& & $(1.96)$ \\
LDRD*FR(-2) & & 2.294 \\
& & $(1.50)$ \\
LDRD*FR(-1) & & $-\mathbf{2 . 8 3 1}$ \\
& & $\mathbf{- 1 . 9 7 )}$ \\
LDRD*FR(0) & & 0.013 \\
& & $(0.00)$ \\
LDRD*FR(+1) & & 0.684 \\
& & $(0.26)$ \\
LDRD*FR(+2) & & 0.399 \\
& & $(0.24)$ \\
Size & & 0.135 \\
& & $(2.62)$ \\
BM & 0.354 \\
Momentum & $(2.32)$ & $(2.87)$ \\
& 0.240 & 0.196 \\
R\&D & $(2.49)$ & $(3.05)$ \\
& 0.155 & -2.583 \\
\end{tabular}




\section{Table IX}

\section{Change in Cost of Capital}

This table reports unadjusted changes (Panel A) and abnormal changes (Panel B) in cost of capital (in \%). The cost of capital for each sample observation is obtained from the Carhart (1997) model. We use a window of 120 months around R\&D decreases (from July of year $t-5$ to June of year $t+5$, where year $t$ is the ending year of R\&D decreases) to estimate the parameters of the following model for each sample firm:

$$
\begin{gathered}
R_{i \tau}=R_{f \tau}+a_{-i}+a_{\Delta i} D_{\tau}+b_{-i}\left(R_{m \tau}-R_{f \tau}\right)+b_{\Delta i} D_{\tau}\left(R_{m \tau}-R_{f \tau}\right)+ \\
S_{-i} S M B_{\tau}+s_{\Delta i} D_{\tau} S M B_{\tau}+h_{-i} H M L_{\tau}+h_{\Delta i} D_{\tau} H M L_{\tau}+m_{-i} W M L_{\tau}+m_{\Delta i} D_{\tau} W M L_{\tau}+\varepsilon_{i \tau},
\end{gathered}
$$

where $R_{i \tau}$ is the monthly return on sample firm $i, R_{f \tau}$ is the risk-free rate, $R_{m \tau}$ is the CRSP value-weighted market index return, $S M B_{\tau}$ is the small-firm portfolio return minus big-firm portfolio return, $H M L_{\tau}$ is the high book-to-market portfolio return minus low book-to-market portfolio return, $W M L_{\tau}$ is the past winner portfolio return minus past loser portfolio return, and $D_{\tau}$ is a dummy variable, which is equal to 1 if month $\tau$ is on or after July of year $t$, and zero otherwise; $a_{-i}$ is the abnormal return and $b_{-i}, s_{-i}, h_{-i}$ and $m_{-i}$ are the factor loadings of firm $i$ during the period of year $t-5$ to year $t ; a_{\Delta i}$ is the change in abnormal return and $b_{\Delta i}, s_{\Delta i}, h_{\Delta i}$ and $m_{\Delta i}$ are the changes in factor loadings of firm $i$ during the period of year $t+1$ to year $t+5$. The cost of capital is evaluated at the average $R_{f}, R_{m}-R_{f}$, and risk premiums of $S M B, H M L$, and WML over the period of 1976 to 2006. The abnormal cost of capital is equal to the unadjusted cost of capital minus the cost of capital of a control firm matched with market value of equity, book-to-market, and prior one year return (excluding month -1) between $70 \%$ and $130 \%$ of the market value of equity, book-to-market and prior one year return (excluding month -1 ) at the end of year $t$, respectively, and the closest R\&D. Numbers in parentheses are $t$-statistics for mean tests and $p$-values of Wilcoxon rank tests for medians.

\begin{tabular}{lcc}
\hline & Mean & Median \\
\hline Before R\&D decreases & Panel A: Unadjusted cost of capital & \\
After R\&D decreases & 13.273 & 13.274 \\
Difference & 10.886 & 12.546 \\
& -2.387 & -1.534 \\
\hline & $(-3.94)$ & $(0.001)$ \\
\hline Before R\&D decreases & Panel B: Abnormal cost of capital & -0.522 \\
After R\&D decreases & 0.464 & $(0.962)$ \\
& $(0.60)$ & -1.211 \\
Difference & -1.978 & $(0.037)$ \\
& $(-2.52)$ & -2.099 \\
\hline
\end{tabular}


Table X

Fama-MacBeth Monthly Cross-Sectional Regressions

This table shows the Fama-MacBeth (1973) cross-sectional regressions for all firms covered on both Compustat and CRSP databases. The dependent variable is the raw return and monthly regressions are carried out from July 1976 to December 2006. All independent variables, except momentum, which is updated monthly, are updated annually in June of year $y+1$ or at the year-end of fiscal year $y$ and are employed in the following 12 monthly regressions (from July of year $y+1$ to June of year $y+2)$. Size is the log market value of equity in millions, $B M$ is the book-to-market, and Momentum is the 11-month prior buy-and-hold return ending on one month prior to the dependent variable is measured. Asset growth is one-year growth rate of total assets. Liquidity is the trading volume standardized by total shares outstanding. Accruals is the accounting accruals defined in Sloan (1996). Net share issue is the change in split-adjusted shares outstanding as defined in Pontiff and Woodgate (2008). Net share issue dummy is equal to 1 if the net share issue is not available, and zero otherwise. Capital expenditure is the abnormal capital expenditure defined in Titman, Wei, and Xie (2004). Capital expenditure dummy is equal to 1 if the abnormal capital expenditure is not available, and zero otherwise. $R \& D$ is the research and development expenditure divided by average total assets. $L D R D$ is equal to 1 if the firm has experienced a large decrease in $\mathrm{R} \& \mathrm{D}$ (i.e., being selected as the sample firm) in the past five years, and zero otherwise. $R \& D$ dummy is equal to 1 if $R \& D$ is missing, and zero otherwise. $R \& D$ follower is a dummy variable equal to 1 if the firm's R\&D is below the industry median (based on three-digit SIC as the industry classification) in the fiscal year $y$, and zero otherwise. $R \& D$ follower $(b) * L D R D$ is equal to 1 if R\&D-decrease firms keep their R\&D below the industry median at the beginning of their R\&D-decrease year, and zero otherwise. Institutional ownership (IO) is defined as total shares owned by institutions, obtained from Thomson Reuters $13 \mathrm{f}$ database, divided by total shares outstanding. IO dummy is equal to 1 if there is no IO information from $13 \mathrm{f}$ database, and zero otherwise. Low IO is an IO dummy that is equal to 1 if the firm's IO is below the industry median at the end of December of year $y$, and zero otherwise. Low $I O(b) * L D R D$ is equal to 1 if the firm is a $\mathrm{R} \& \mathrm{D}$-decrease firm and its IO is below the industry median at the beginning of the R\&D-decrease year, and zero otherwise. Low $Q$ is a dummy variable that is equal to 1 if Tobin's $Q$ is below 1 at the end of December of year $y$. Low $Q(b) * L D R D$ is equal to 1 if the firm is a R\&D-decrease firm and its Tobin's $Q$ is below 1 at beginning of the $R \& D$-decrease year, and zero otherwise. Decrease $Q$ is a dummy variable that is equal to 1 if Tobin's $Q$ from year $y$ to year $y$-1 drops more than $10 \%$ (e.g., from 2 to 1.9 ). Decrease $Q(b) * L D R D$ is equal to 1 if the firm is a R\&D-decrease firm and its Tobin's $Q$ drops more than $10 \%$ at beginning of the R\&D-decrease year, and zero otherwise. $\triangle$ Cost of capital is the change in cost of capital obtained from table IX. Low $Q(b) *$ Decrease $Q(b) * L D R D$ is equal to 1 if the firm is a R\&D-decrease firm and its Tobin's $Q$ is below 1 and drops more than $10 \%$ at beginning of the R\&D-decrease year, and zero otherwise. Decrease in cost of capital equals to $\Delta$ Cost of capital if the cost of capital decreases around R\&D reductions, and zero otherwise. The numbers in parentheses are $t$-statistics adjusted for the heteroskedasticity and autocorrelation in standard errors by using the Newey-West (1987) method. 
Table X (Continued)

\begin{tabular}{|c|c|c|c|c|c|c|c|c|c|}
\hline Model & 1 & 2 & 3 & 4 & 5 & 6 & 7 & 8 & 9 \\
\hline \multirow[t]{2}{*}{ Intercept } & 0.0278 & 0.0307 & 0.0309 & 0.0318 & 0.0298 & 0.0309 & 0.0308 & 0.0320 & 0.0321 \\
\hline & $(6.52)$ & $(5.78)$ & $(6.04)$ & $(6.25)$ & $(5.40)$ & (5.33) & $(6.05)$ & (6.13) & (6.19) \\
\hline \multirow[t]{2}{*}{ Size } & -0.0014 & -0.0014 & -0.0014 & -0.0014 & -0.0013 & -0.0014 & -0.0014 & -0.0014 & -0.0014 \\
\hline & $(-4.37)$ & $(-4.66)$ & $(-4.69)$ & $(-4.94)$ & $(-4.60)$ & $(-4.68)$ & $(-4.65)$ & $(-5.02)$ & $(-5.08)$ \\
\hline \multirow[t]{2}{*}{ BM } & 0.0042 & 0.0043 & 0.0043 & 0.0043 & 0.0045 & 0.0043 & 0.0043 & 0.0045 & 0.0045 \\
\hline & $(6.26)$ & (6.64) & (6.55) & $(6.56)$ & $(6.45)$ & (6.81) & (6.79) & (6.91) & $(6.85)$ \\
\hline \multirow[t]{2}{*}{ Momentum } & 0.0032 & 0.0026 & 0.0026 & 0.0025 & 0.0025 & 0.0026 & 0.0026 & 0.0026 & 0.0027 \\
\hline & $(2.02)$ & $(1.87)$ & $(1.88)$ & $(1.76)$ & $(1.84)$ & $(2.03)$ & (1.96) & $(2.04)$ & (2.09) \\
\hline \multirow[t]{2}{*}{ Assets growth } & -0.0022 & -0.0022 & -0.0021 & -0.0021 & -0.0021 & -0.0021 & -0.0021 & -0.0019 & -0.0020 \\
\hline & $(-5.14)$ & $(-5.04)$ & $(-5.08)$ & $(-4.87)$ & $(-4.85)$ & $(-5.09)$ & $(-5.51)$ & $(-5.21)$ & $(-5.15)$ \\
\hline \multirow[t]{2}{*}{ Liquidity } & -0.0021 & -0.0021 & -0.0021 & -0.0021 & -0.0021 & -0.0021 & -0.0021 & -0.0021 & -0.0020 \\
\hline & $(-3.22)$ & $(-3.29)$ & $(-3.28)$ & $(-3.23)$ & $(-3.29)$ & $(-3.29)$ & $(-3.35)$ & $(-3.26)$ & $(-3.24)$ \\
\hline \multirow[t]{2}{*}{ Accruals } & -0.0123 & -0.0113 & -0.0110 & -0.0116 & -0.0110 & -0.0109 & -0.0114 & -0.0115 & -0.0114 \\
\hline & $(-9.76)$ & $(-10.40)$ & $(-10.72)$ & $(-9.93)$ & $(-10.75)$ & $(-8.92)$ & $(-10.21)$ & $(-9.54)$ & $(-9.42)$ \\
\hline \multirow[t]{2}{*}{ Net share issue } & -0.0052 & -0.0053 & -0.0053 & -0.0051 & -0.0053 & -0.0053 & -0.0053 & -0.0052 & -0.0052 \\
\hline & $(-5.52)$ & $(-5.94)$ & $(-5.94)$ & $(-5.27)$ & $(-6.10)$ & $(-5.96)$ & $(-6.10)$ & $(-5.37)$ & $(-5.28)$ \\
\hline \multirow[t]{2}{*}{ Net share issue dummy } & -0.0038 & -0.0035 & -0.0035 & -0.0022 & -0.0036 & -0.0034 & -0.0037 & -0.0025 & -0.0023 \\
\hline & $(-3.46)$ & $(-3.28)$ & $(-3.26)$ & $(-2.60)$ & $(-3.44)$ & $(-3.18)$ & $(-3.57)$ & $(-2.93)$ & $(-2.68)$ \\
\hline \multirow[t]{2}{*}{ Capital expenditure } & -0.0008 & -0.0009 & -0.0009 & -0.0009 & -0.0009 & -0.0009 & -0.0009 & -0.0009 & -0.0009 \\
\hline & $(-1.40)$ & $(-1.40)$ & $(-1.39)$ & $(-1.39)$ & $(-1.40)$ & $(-1.39)$ & $(-1.40)$ & $(-1.36)$ & $(-1.37)$ \\
\hline \multirow[t]{2}{*}{ Capital expenditure dummy } & -0.0017 & -0.0015 & -0.0015 & -0.0015 & -0.0015 & -0.0013 & -0.0015 & -0.0013 & -0.0013 \\
\hline & $(-0.79)$ & $(-0.64)$ & $(-0.65)$ & $(-0.64)$ & $(-0.63)$ & $(-0.56)$ & $(-0.66)$ & $(-0.55)$ & $(-0.53)$ \\
\hline \multirow[t]{2}{*}{$\mathrm{R} \& \mathrm{D}$} & 0.0283 & 0.0281 & 0.0228 & 0.0281 & 0.0287 & 0.0284 & 0.0272 & 0.0235 & 0.0227 \\
\hline & $(2.82)$ & (2.45) & $(1.83)$ & (2.45) & $(2.51)$ & $(2.43)$ & $(2.37)$ & $(1.86)$ & $(1.80)$ \\
\hline \multirow[t]{2}{*}{ R\&D dummy } & -0.0012 & -0.0018 & -0.0014 & -0.0016 & -0.0017 & -0.0018 & -0.0020 & -0.0014 & -0.0014 \\
\hline & $(-2.97)$ & $(-4.18)$ & $(-4.01)$ & $(-4.16)$ & $(-4.12)$ & $(-4.22)$ & $(-4.43)$ & $(-3.79)$ & $(-3.77)$ \\
\hline \multirow[t]{2}{*}{ LDRD } & 0.0027 & 0.0023 & 0.0019 & 0.0022 & 0.0022 & 0.0018 & 0.0023 & 0.0019 & 0.0018 \\
\hline & $(4.23)$ & $(4.20)$ & $(3.88)$ & $(4.28)$ & $(4.34)$ & $(3.62)$ & $(4.24)$ & $(4.06)$ & $(3.93)$ \\
\hline \multirow[t]{2}{*}{ R\&D follower } & & & -0.0019 & & & & & -0.0017 & -0.0018 \\
\hline & & & $(-2.87)$ & & & & & $(-2.61)$ & $(-2.66)$ \\
\hline \multirow[t]{2}{*}{ R\&D follower (b)*LDRD } & & & 0.0010 & & & & & 0.0009 & 0.0010 \\
\hline & & & $(0.66)$ & & & & & $(0.57)$ & $(0.70)$ \\
\hline IO dummy & & & & -0.0023 & & & & -0.0022 & -0.0023 \\
\hline & & & & $(-2.59)$ & & & & $(-2.56)$ & $(-2.57)$ \\
\hline Low IO & & & & 0.0000 & & & & 0.0002 & 0.0001 \\
\hline & & & & $(0.13)$ & & & & $(0.66)$ & $(0.50)$ \\
\hline Low IO (b)*LDRD & & & & 0.0007 & & & & 0.0001 & 0.0000 \\
\hline & & & & $(0.71)$ & & & & $(0.16)$ & $(0.00)$ \\
\hline Low Q & & & & & 0.0001 & & & 0.0001 & -0.0002 \\
\hline & & & & & $(0.18)$ & & & $(0.20)$ & $(-0.41)$ \\
\hline Low Q (b)*LDRD & & & & & 0.0027 & & & & \\
\hline & & & & & $(2.64)$ & & & & \\
\hline Decrease Q & & & & & & -0.0004 & & -0.0004 & -0.0005 \\
\hline & & & & & & $(-0.69)$ & & $(-0.73)$ & $(-1.00)$ \\
\hline Decrease Q (b)*LDRD & & & & & & 0.0043 & & & \\
\hline & & & & & & $(6.32)$ & & & \\
\hline$\Delta$ Cost of capital & & & & & & & 0.0005 & 0.0005 & 0.0005 \\
\hline & & & & & & & $(6.30)$ & $(6.24)$ & $(4.87)$ \\
\hline$\Delta$ Cost of capital*LDRD & & & & & & & -0.0002 & -0.0002 & \\
\hline & & & & & & & $(-2.83)$ & $(-2.92)$ & \\
\hline Low Q(b)* Decrease Q(b)*LDRD & & & & & & & & 0.0042 & \\
\hline & & & & & & & & $(2.47)$ & \\
\hline Low Q(b)* Decrease Q(b)*LDRD & & & & & & & & & -0.0031 \\
\hline * decrease in cost of capital & & & & & & & & & $(-2.25)$ \\
\hline Industry dummies & No & Yes & Yes & Yes & Yes & Yes & Yes & Yes & Yes \\
\hline Average R-square & $4.48 \%$ & $5.53 \%$ & $5.72 \%$ & $5.76 \%$ & $5.73 \%$ & $5.73 \%$ & $6.27 \%$ & $6.96 \%$ & $6.93 \%$ \\
\hline
\end{tabular}

